
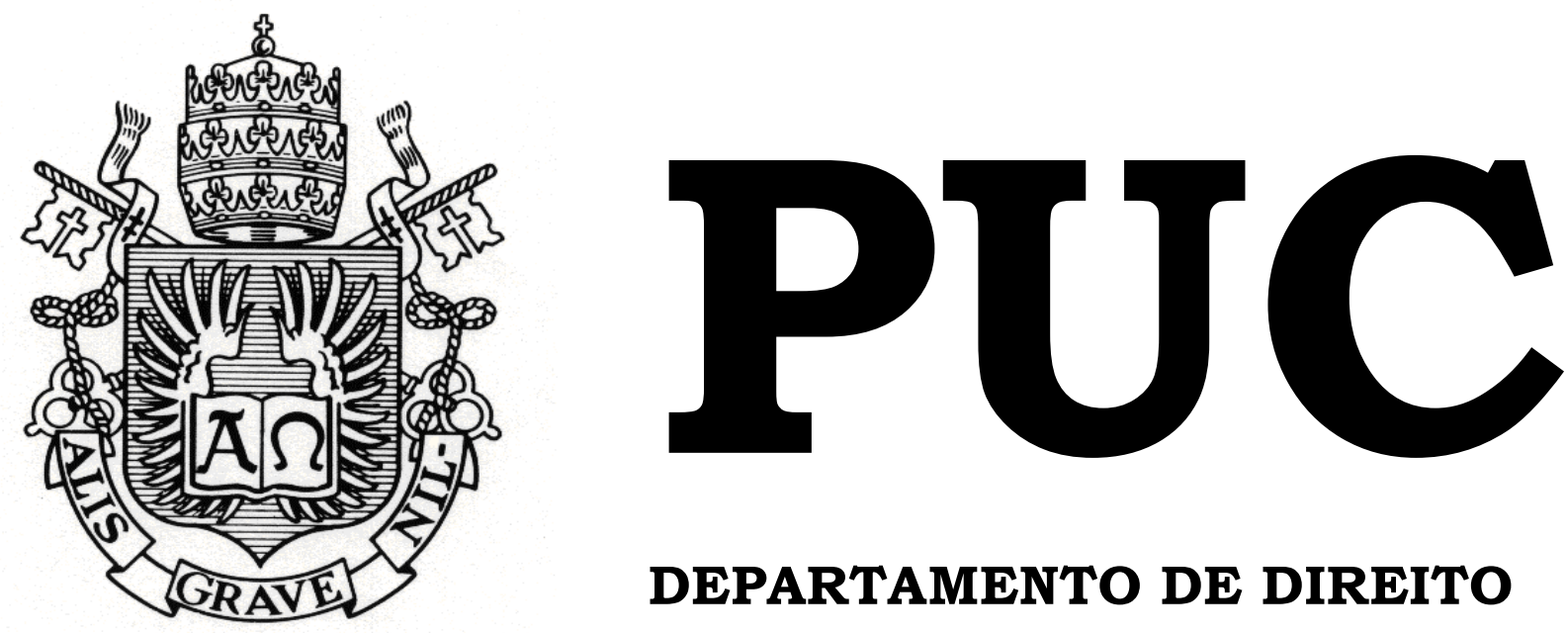

DEPARTAMENTO DE DIREITO

\title{
ASPECTOS DAS FALSAS MEMÓRIAS NO PROCESSO PENAL BRASILEIRO
}

\author{
Por
}

BÁRBARA BARBOSA DE SOUZA

ORIENTADOR: ADOLFO BORGES

2019.1

PONTIFÍCIA UNIVERSIDADE CATÓLICA DO RIO DE JANEIRO

RUA MARQUÊS DE SÃO VICENTE, 225 - CEP 22451-900

RIO DE JANEIRO - BRASIL 


\title{
ASPECTOS DAS FALSAS MEMÓRIAS NO PROCESSO PENAL BRASILEIRO
}

\author{
por
}

BÁRBARA BARBOSA DE SOUZA

Monografia apresentada ao

Departamento de Direito da

Pontifícia Universidade Católica do

Rio de Janeiro (PUC-Rio) para a

obtenção do Título de Bacharel em Direito.

Orientador: Prof. Adolfo Borges 


\section{AGRADECIMENTOS}

Me faltam palavras para agradecer a todas as pessoas maravilhosas que eu tenho a honra de ter em minha vida, no entanto, deixo o registro de um singelo agradecimento aos que, de alguma forma, contribuíram na elaboração deste trabalho.

Primeiramente, minha família, Luiza, Alexandre e Manuel, que sempre me apoiaram em todas as fases da vida, sem nunca medir esforços para que eu chegasse até aqui e por terem me ensinado meu maior referencial de amor;

Ao meu orientador, Adolfo, que, desde do início, se dedicou ao meu tema e prestou todo o auxílio necessário para que o trabalho fosse desenvolvido da melhor forma. Obrigada, de coração, por toda a inspiração e dedicação;

A todas as professoras e professores que me guiaram durante a vida acadêmica e que, cada qual a seu modo, se esforçaram para despertar o meu interesse pelo conhecimento;

A todos os meus amigos que acompanharam essa jornada e me viram abdicar de tantos momentos em prol de um objetivo maior. Em especial, ao meu namorado, Caio, por todo apoio e companheirismo, e ao grupo Palmeira, por tudo que vivemos ao longo desses cinco anos de aprendizado e acima de tudo, de amizade. 
As convicções são inimigas mais perigosas da verdade do que as mentiras.

Friedrich Nietzsche 


\section{RESUMO}

SOUZA, Bárbara Barbosa de. Aspectos das Falsas Memórias no Processo Penal Brasileiro. Rio de Janeiro: 2019: 75 p. Monografia de final de curso. Departamento de Direito da Pontifícia Universidade Católica do Rio de Janeiro - PUC-Rio.

A Interdisciplinariedade do Direito e da Psicologia. A importância de reconhecer o mito da verdade no processo penal. Polêmica quanto a supremacia da prova oral no processo penal - v.g. depoimento de testemunhas e interrogatório da vítima - e, como consequência, na condenação ou absolvição do réu. Incidência das falsas memórias nos depoimentos em juízo, com especial atenção ao depoimento infantil. Técnicas de entrevistas apropriadas para a colheita dos depoimentos como forma de aumentar a qualidade do testemunho.

Palavras-Chave: Psicologia jurídica, memória, processo penal, testemunho, falsas memórias. 


\section{SUMÁRIO}

INTRODUÇÃ

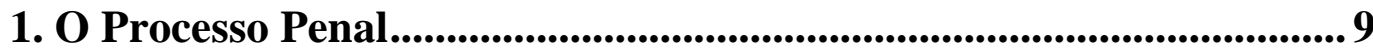

1.1. Processo Penal brasileiro e sua leitura constitucional ......................... 9

1.2. Princípios fundamentais do processo penal brasileiro ....................... 10

1.2.1. Princípio do devido processo legal.................................................. 11

1.2.2. Princípio da presunção de inocência ................................................ 13

1.2.3. Princípio do contraditório e da ampla defesa ................................... 15

1.2.4. Princípio do livre convencimento motivado do juiz ...................... 17

1.3. Sistemas processuais penais ............................................................. 19

2. A prova No Processo Penal ......................................................................... 23

2.1. Considerações sobre a prova no processo penal ................................ 23

2.2. O mito da verdade na lógica processual penal .................................. 24

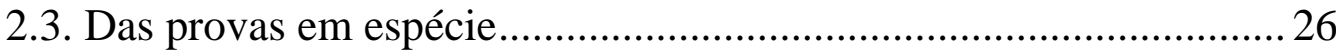

2.4. Particularidades da prova testemunhal .............................................. 30

2.4.1. Fases da formação do testemunho................................................... 30

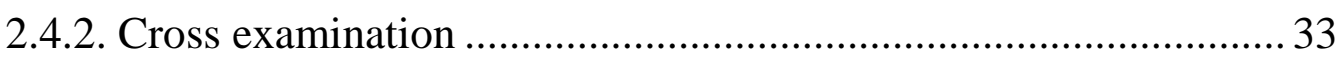

3. Relação Entre O Direito E A Psicologia ..................................................... 35

3.1. A interseção do Direito e da Psicologia: A Psicologia Jurídica ........ 35

3.2. Áreas em que a Psicologia Jurídica influencia a aplicação do Direito

4. Falsas Memórias no Contexto do Processo Penal..................................... 41

4.1. Memória e a influência da emoção...................................................... 41 
4.2. Falsas memórias ....................................................................... 43

4.2.1. Teorias explicativas do fenômeno das falsas memórias............... 45

4.2.2. Diferenças individuais na formação de falsas mnemônicas .......... 49

4.3. Falsas memórias e a prova penal ................................................. 50

4.3.1. Famigerados casos de erros judiciais causados por falhas na

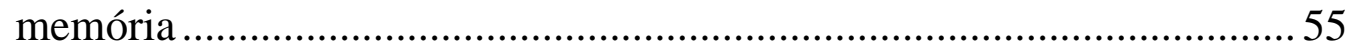

4.3.2. Depoimento infantil e suas peculiaridades .............................. 57

4.3.3. Sugestões para a redução das falsas memórias .......................... 60

CONSIDERAÇÕES FINAIS.................................................................... 67

REFERÊNCIAS BIBLIOGRÁFICAS .................................................... 71 


\section{INTRODUÇÃO}

Este trabalho pretende abordar como a problemática das falhas mnemônicas, fenômeno que decorre do funcionamento normal da memória, interfere na confiabilidade do testemunho como meio de prova no processo penal. Para isso, articulam-se os diferentes aspectos da prova testemunhal, inseridos na lógica do processo penal como atividade retrospectiva com os estudos realizados acerca das falsas memórias, que se revelam quando alguém lembra de um evento que não ocorreu ou se lembra de forma distorcida sobre o acontecido.

O funcionamento da memória, bem como suas falhas, sempre instigou o interesse de diversas áreas do saber, inclusive da psicologia forense. Desde o final do século passado, nota-se uma particular preocupação com os efeitos das falhas na memória na prova testemunhal e suas consequências para o âmbito judicial, com especial atenção ao testemunho infantil. Não por acaso, nesta mesma época, observou-se também um considerável impulso nas pesquisas relacionadas a esse tema. Portanto, constata-se a relevância do presente tema tanto para o Direito quanto para a Psicologia.

Nessa perspectiva, os crescentes estudos sobre as falsas memórias se dedicam, entre outros enfoques, à construção de teorias explicativas e possibilidade de controle de tais falhas. Além disso, se debruça na análise das variáveis que afetam, não só o processo de aquisição na memória, como também sua conservação e evocação. Apesar das pesquisas ainda estarem em curso e de existirem muitas perguntas sem respostas, os resultados até agora obtidos representam importantes descobertas e permitem vislumbrar as consequências das falsas memórias para o processo penal.

Destaca-se, então, a importância da interdisciplinariedade entre o Direito e a Psicologia, não só na produção de conhecimento sobre o tema, como também na adequação e aplicação deste à rotina forense. Visa-se, 
como isso, desenvolver formas de reduzir os danos provocados pelas falhas na memória à prova testemunhal, bem como meios mais apropriados para entrevistar os depoentes, respeitando suas especificidades. Assim, cria-se a possibilidade de proporcionar um relato mais fidedigno à realidade, como forma de garantir um julgamento mais justo.

Em suma, analisa-se o funcionamento da memória e as circunstâncias que propiciam a formação de falsas lembranças, com o foco nas consequências destas para a produção da prova oral no processo penal, precipuamente nos casos em que não se encontram disponíveis outras provas para a análise do julgador. 


\section{CAPÍTULO 1 - O PROCESSO PENAL}

\subsection{Processo Penal brasileiro e sua leitura constitucional}

O Direito processual penal é o conjunto de normas jurídicas que regulam a persecução penal, ou seja, o modo, os meios e os órgãos competentes para realizar a pretensão punitiva do Estado, sempre que uma infração penal é cometida. Dessa forma, o poder judiciário se encarrega de aplicar o direito material ao caso concreto ${ }^{1}$. Assim, o processo penal se revela como uma sequência de atos, logicamente organizados, que culminará na resolução do conflito social e na eventual aplicação da sanção estatal.

Historicamente, tanto o processo penal quanto o direito penal, per si, são tidos como garantias. Este porque estabelece o direito material, previamente definido, limitador do poder punitivo estatal, enquanto aquele determina as regras de aplicação dessa legislação, respaldados nos preceitos estabelecidos pela Constituição Federal, com a finalidade de evitar os excessos cometidos pelo Estado contra os indivíduos.

De acordo com James Goldschmidt, referido por Aury:

Os princípios de política processual de uma nação não são outra coisa do que segmento da sua política estatal em geral; e o processo penal de uma nação não é senão um termômetro dos elementos autoritários ou democráticos da sua Constituição. A uma Constituição autoritária vai corresponder um processo penal autoritário, utilitarista (eficiência antigarantista). Contudo, a uma constituição democrática, como a nossa, necessariamente deve corresponder um processo penal democrático, visto como instrumento a serviço da máxima eficácia do sistema de garantias constitucionais do indivíduo ${ }^{2}$.

O processo penal brasileiro, como todos os ramos do direito, sofreu diversas mudanças com o passar do tempo. Nesse contexto, merece

\footnotetext{
$1 \quad$ NUCCI, Guilherme de Souza. Manual de processo penal e execução penal. $14^{\mathrm{a}}$ ed. Rio de Janeiro: Forense, 2017. p. 27.

GOLDSCHMIDT, James. Problemas Jurídicos y Políticos del Proceso Penal. Barcelona: Bosh, 1935. p. 67 apud LOPES JÚNIOR, Aury. Direito processual penal. $11^{\mathrm{a}}$ ed. São Paulo: Saraiva, 2014. p. 28.
} 
destaque a redemocratização em 1988 e o advento da Carta Magna, que ocasionou uma mudança de paradigma e o transformou em um processo penal democrático, balizado pelas garantias defendidas em nossa Constituição.

Sobre esse tema, Nucci assevera:

O Código de Processo Penal (Decreto-Lei 3.689, de 3 de outubro de 1941) nasceu sob o Estado Novo, em plena ditadura da era Vargas, não podendo servir de base à construção de um corpo de normas jurídicas aplicável de per si, ignorando-se as constantes e sucessivas mutações da ordem constitucional brasileira, até culminar com a Constituição de 1988, nitidamente uma das mais democráticas que já tivemos ${ }^{3}$.

Dessa forma, o processo penal brasileiro contemporâneo, assim como as demais leis infraconstitucionais, deve se ater à perspectiva constitucional vigente, de maneira que a sistemática do processo penal seja interpretada e executada à luz da Constituição Federal. Não há outra maneira de garantir que serão respeitados os direitos e as garantias conquistados no processo de democratização, importante passo para a concretização da humanização do Direito Penal.

\title{
1.2. Princípios fundamentais do processo penal brasileiro
}

Miguel Reale nos ensina brilhantemente que:

Princípios gerais de direito são enunciações normativas de valor genérico, que condicionam e orientam a compreensão do ordenamento jurídico, quer para a sua aplicação e integração, quer para a elaboração de novas normas. Cobrem, desse modo, tanto o campo da pesquisa pura do Direito quanto o de sua atualização prática ${ }^{4}$.

Por vezes, valores, princípios, garantias e direitos humanos fundamentais se confundem ou se sobrepõe, pois esses conceitos possuem

\author{
NUCCI, 2017, p. 28. \\ REALE, Miguel. Lições preliminares de direito. $27^{\mathrm{a}}$ ed. São Paulo: Saraiva, 2002. p.
} 304. 
uma profunda ligação e relação de interdependência. Não por acaso, os princípios do processo penal estão elencados na Constituição, em sua maioria, no art. $5^{\circ}$, ao lado de diversas outras garantias e direitos fundamentais ${ }^{5}$. Dessa forma, os princípios processuais penais estão intimamente conectados com o restante do sistema de normas em que eles estão inseridos. Cumpre ressaltar que, dentre os princípios que foram eleitos para integrarem o conteúdo da Carta Magna, seja explícita ou implicitamente, muitos já eram consagrados pela doutrina e jurisprudência pátria.

Nesse contexto, expõe Di Gesu:

\begin{abstract}
Através dos princípios busca-se não somente a simples regulação de um caso ou então, a supressão das lacunas da lei. Para além disso, através da principiologia da prova almeja-se a sistematização da matéria, diante da necessidade de o intérprete do direito compatibilizar e adaptar os direitos e garantias constitucionais a um sistema atrasado e de origem inquisitorial como o do Código de Processo Penal brasileiro ${ }^{6}$.
\end{abstract}

No presente trabalho, se revela oportuno esmiuçar alguns dos princípios do processo penal constitucionalmente previstos, quais sejam, o devido processo legal (art. $5^{\circ}, \mathrm{LIV}, \mathrm{CF}$ ), a presunção de inocência (art. $5^{\circ}$, LVII, CF), o contraditório e a ampla defesa (art. $5^{\circ}, \mathrm{LV}, \mathrm{CF}$ ) e o princípio da motivação das decisões judiciais (art. 93, IX, CF).

\title{
1.2.1. Princípio do devido processo legal
}

Primeiramente, o princípio do devido processo legal, previsto pelo art. $5^{\circ}$, LIV, CF: "ninguém será privado da liberdade ou de seus bens sem o devido processo legal”. Esse princípio estabelece o respeito ao processo penal, isto é, às regras processuais que tem o condão de garantir um julgamento justo. Cumpre ressaltar que essas regras devem estar

DI GESU, Cristina. Prova penal e falsas memórias. Porto Alegre: Livraria do Advogado, 2019. p. 57. 
anteriormente previstas em lei e não podem ser alteradas pelas partes no decorrer do processo.

Nesse sentido, contribui Nucci:

O devido processo legal deita suas raízes no princípio da legalidade, garantindo ao indivíduo que somente seja processado e punido se houver lei penal anterior definindo determinada conduta como crime, cominando-lhe pena. Além disso, modernamente, representa a união de todos os princípios penais e processuais penais, indicativo da regularidade ímpar do processo criminal ${ }^{7}$.

Não obstante, caso haja uma mudança na lei processual penal, a doutrina distingue as normas puramente processuais das chamadas normas mistas, ou seja, normas processuais com aspectos materiais, para determinar a aplicabilidade da nova lei. Com relação às primeiras, que dispõem sobre o desenvolvimento do processo e seus diferentes institutos, se aplica o disposto no art. $2^{\circ}$ do Código de Processo Penal ${ }^{8}$, que determina a aplicação imediata da lei, o que significa dizer que ela incidirá apenas nos atos processuais praticados após a sua entrada em vigor, não alterando os já praticados. No entanto, com relação às normas mistas, que são processuais mas dispõem sobre a pretensão punitiva, aplica-se a mesma regra das normas materiais, qual seja, se a nova lei for benéfica ao réu, retroage ${ }^{9}$.

Ademais, a inobservância do devido processo legal pode acarretar nulidades na ação penal, que podem ser absolutas ou relativas, que se diferencia das primeiras pois permitem o convalescimento do ato. A falta de citação válida do réu e a inversão dos atos processuais, como por exemplo, quando o réu é ouvido antes das testemunhas, são exemplos de nulidades absolutas decorrentes do descumprimento das formalidades legais ${ }^{10}$.

NUCCI, 2017, p. 33.

Art. $2^{\underline{0}}$ A lei processual penal aplicar-se-á desde logo, sem prejuízo da validade dos atos realizados sob a vigência da lei anterior.

$9 \quad$ LOPES JÚNIOR, 2014, p. 169.

10 GONÇALVES, Victor Eduardo Rios; REIS, Alexandre Cebrian Araújo. Direito processual penal esquematizado. LENZA, Pedro (Coord.). $7^{\text {a }}$ ed. São Paulo: Saraiva Educação, 2018. 


\subsubsection{Princípio da presunção de inocência}

Em seguida, o princípio da presunção de inocência, também conhecido como o princípio da não culpabilidade, disposto no art. $5^{\circ}$, LVII, $\mathrm{CF}$, segundo o qual: "ninguém será considerado culpado até o trânsito em julgado de sentença penal condenatória". Assim, a presunção de inocência permanece até que haja o esgotamento dos recursos cabíveis e, por consequência, o trânsito em julgado.

Sobre esse tema, ensina Nucci:

Tem por objetivo garantir, primordialmente, que o ônus da prova cabe à acusação e não à defesa. As pessoas nascem inocentes, sendo esse o seu estado natural, razão pela qual, para quebrar tal regra, torna-se indispensável ao Estado-acusação evidenciar, com provas suficientes, ao Estado-juiz, a culpa do réu ${ }^{11}$.

A presunção de inocência se relaciona com o princípio do In dubio pro reu, na medida em que este, nada mais é, do que a prevalência do estado de inocência do réu, uma vez que preconiza que, em caso de dúvida, prevalece o interesse do mesmo. Da mesma forma, se o estado originário é a inocência, cabendo à acusação a prova do contrário, firma-se, nesse contexto, o direito ao silêncio, por meio do princípio da não auto acusação, que se revela no direito do réu de não produzir prova contra si mesmo ${ }^{12}$. Cumpre ressaltar que, caso o acusado opte por permanecer em silêncio, isso não poderá ser utilizado contra ele.

Outrossim, a presunção de inocência configura não só um princípio, mas sim, um verdadeiro dever de tratamento. Dessa forma, não basta que o acusado não ser considerado formalmente culpado sem que haja o trânsito em julgado, é crucial que ele seja tratado como inocente no decorrer do processo, tanto na sua dimensão interna quanto externa. Enquanto esta diz respeito à publicidade e abuso midiático na estigmatização do réu, aquela se 
refere ao tratamento do juiz, que deve garantir que a carga probatória seja exclusivamente da acusação ${ }^{13}$.

Além disso, a presunção de inocência tem influência não só na carga probatória do processo penal, mas também serve como restrição à prisão. Considerando que a liberdade é a regra, apenas se admite a prisão após o trânsito em julgado de sentença penal condenatória ou em casos excepcionais, admitem-se as prisões cautelares, como a prisão em flagrante, temporária e preventiva. A primeira é regulada pelos arts. 301 a 310 do referido Código ${ }^{14}$. Já as demais, só podem ser decretadas por ordem escrita e fundamentada do juiz competente, sendo a temporária regulada pela Lei Especial 7.960/89, enquanto a preventiva deve respeitar os requisitos dos $\operatorname{artigos} 312^{15}$ e $313^{16}$ do Código de Processo Penal.

De certo, esse princípio não foi, historicamente, um consenso. Apesar de ter tido origem longínqua no Direito Romano, "foi seriamente atacada e até invertida na inquisição da Idade Média"17. Contudo, após certa disputa durante os séculos, foi amplamente consagrada pela democracia contemporânea, inclusive estando expressamente prevista em nossa lei maior. Dessa forma, cumpre registrar o descontentamento com a decisão do supremo que permite a prisão após condenação em segunda instância, ou seja, antes do trânsito em julgado ${ }^{18}$, uma vez que representa, claramente,

13 LOPES JÚNIOR, 2014, p. 145.

14 GONÇALVES; REIS, 2018. p. 319.

15 Art. 312. A prisão preventiva poderá ser decretada como garantia da ordem pública, da ordem econômica, por conveniência da instrução criminal, ou para assegurar a aplicação da lei penal, quando houver prova da existência do crime e indício suficiente de autoria. (Redação dada pela Lei n' 12.403, de 2011).

Art. 313. Nos termos do art. 312 deste Código, será admitida a decretação da prisão preventiva: (Redação dada pela Lei ${ }^{\circ} 12.403$, de 2011). I - nos crimes dolosos punidos com pena privativa de liberdade máxima superior a 4 (quatro) anos; (Redação dada pela Lei $\mathrm{n}^{\circ} 12.403$, de 2011).

17 LOPES JÚNIOR, 2014, p. 142.

18 EMENTA: CONSTITUCIONAL. HABEAS CORPUS. PRINCÍPIO CONSTITUCIONAL DA PRESUNÇÃO DE INOCÊNCIA (CF, ART. 5º LVII). SENTENÇA PENAL CONDENATÓRIA CONFIRMADA POR TRIBUNAL DE SEGUNDO GRAU DE JURISDIÇÃO. EXECUÇÃO PROVISÓRIA. POSSIBILIDADE.

1.A execução provisória de acórdão penal condenatório proferido em grau de apelação, ainda que sujeito a recurso especial ou extraordinário, não compromete o princípio constitucional da presunção de inocência afirmado pelo artigo $5^{\circ}$, inciso LVII da Constituição Federal. 
uma afronta ao princípio da presunção de inocência. Assim, as palavras do advogado e professor de direito penal, Reinaldo Santos de Almeida:

A decisão reduziu a pó de traque a garantia da presunção constitucional de inocência com consequências negativas desastrosas para milhares de brasileiros que hoje são e no futuro serão vítimas da fúria punitiva do Estado, isto é, um desserviço à Constituição e à democracia no país ${ }^{19}$.

\subsubsection{Princípio do contraditório e da ampla defesa}

Ato contínuo, analisaremos o princípio do contraditório e da ampla defesa, que se encontra previsto no art. $5^{\circ}, \mathrm{LV}$, da Constituição Federal, assim redigido: "aos litigantes, em processo judicial ou administrativo, e aos acusados em geral são assegurados o contraditório e ampla defesa, com os meios e recursos a ela inerentes". Embora previstos no mesmo dispositivo constitucional, apresentam conteúdos diferentes, como veremos a seguir.

Nas lições de Gonçalves:

Em decorrência do princípio do contraditório as partes devem ser ouvidas e ter oportunidades de manifestação em igualdade de condições, tendo ciência bilateral dos atos realizados e dos que irão se realizar, bem como oportunidade para produzir prova em sentido contrário àquelas juntadas aos autos ${ }^{20}$.

O contraditório se revela na própria dialética do processo. Segundo Lopes Jr., "O contraditório é uma nota característica do processo, uma exigência política, e mais do que isso, se confunde com a própria essência do processo" $" 21$.

Di Gesu destaca a importância da informação para a garantia do contraditório, uma vez que para refutar determinado ato realizado pela parte contrária, é fundamental a ciência do mesmo, sendo válida essa ideia tanto

2. Habeas corpus denegado. STF- HC: 126.292 SP, Relator: ministro TEORI ZAVASCKI, Data de Julgamento: 17/02/2016.

19 ALMEIDA, Renato Santos de. Disponível em: https://www.conjur.com.br/2018-abr05/especialistas-analisam-decisao-stf-aceita-prisao-antecipada. Acesso em: 8 abr. 2019.

20 GONÇALVES; REIS, 2018, p. 68.

21 LOPES JÚNIOR, 2014, p. 146. 
para a acusação quanto para a defesa. Portanto, o juiz deve garantir o acesso à informação e oportunizar a manifestação das partes. Porém, ressalva o direito da defesa em não se manifestar, respeitando o direito ao silêncio ${ }^{22}$.

Noutro giro, a ampla defesa se consubstancia em ter meios efetivos que permitam realizar a defesa face à acusação, sendo a junção da defesa técnica com a defesa pessoal. Ainda de acordo com Gonçalves, sobre tal princípio:

Por seu turno, o princípio da ampla defesa obriga o juiz a observar o pleno direito de defesa aos acusados em ação penal. Em razão disso, ainda que o réu diga que não quer ser defendido, o juiz deverá nomear-lhe defensor. Ademais, se o advogado, ainda que constituído, apresentar defesa insuficiente, o juiz deverá declarar o réu indefeso e dar a ele prazo para constituir novo defensor, sob pena de nulidade do julgamento ${ }^{23}$.

Em complementação a esse pensamento, leciona Nereu Giacomolli:

A ampla defesa deve ser efetiva, não garantindo seu exercício a simples constituição ou nomeação de um defensor. A defesa deve produzir uma antítese firme e consistente à tese acusatória, utilizando-se dos meios disponíveis para rebatê-la. Ademais, ainda enfatiza que meras alegações, abstratas e genéricas, sem exame do conteúdo do processo, embora configurem a defesa sob o ponto de vista forma, não implicam o reconhecimento desta sob o ponto de vista substancial $^{24}$.

O princípio da ampla defesa se relaciona intimamente com o princípio da paridade de armas, sendo aquele fundamental para a efetivação deste. A paridade de armas, nada mais é, que oferecer à defesa, no decorrer do processo, os mesmos meios e condições da acusação. Sua importância se revela no fato do réu ser "considerado, no processo, parte hipossuficiente por natureza, uma vez que o Estado é sempre mais forte, agindo por órgãos constituídos e preparados" 25 . Por esse motivo apontado é que a ampla

\footnotetext{
$22 \quad$ DI GESU, 2019, p. 67.

23 GONÇALVES; REIS, 2018, p. 68.

24 GIACOMOLLI, Nereu. Juizados Especiais Criminais. Lei 9.0099/95. $2^{\mathrm{a}}$ ed. Porto Alegre: Livraria do Advogado, 2002. p. 48-49.

25 NUCCI, 2017, p. 35-36.
} 
defesa concede, ainda, direitos ao réu, como a faculdade de ajuizar o pedido de revisão criminal.

Do mesmo modo, a ampla defesa guarda relação com a imparcialidade do juiz, como assevera Aury:

A defesa técnica é considerada indisponível, pois, além de ser uma garantia do sujeito passivo, existe um interesse coletivo na correta apuração do fato. Trata-se, ainda, de verdadeira condição de paridade de armas, imprescindível para a concreta atuação do contraditório. Inclusive, fortalece a própria imparcialidade do juiz, pois, quanto mais atuante e eficiente forem ambas as partes, mais alheio ficará o julgador (terzietà $=$ alheamento $)^{26}$.

\subsubsection{Princípio do livre convencimento motivado do juiz}

Por fim, o princípio contido no artigo 93, IX, da Constituição Federal:

[...] todos os julgamentos dos órgãos do Poder Judiciário serão públicos, e fundamentadas todas as decisões, sob pena de nulidade, podendo a lei limitar a presença, em determinados atos, às próprias partes e a seus advogados, ou somente a estes, em casos nos quais a preservação do direito à intimidade do interessado no sigilo não prejudique o interesse público à informação; $\underline{\text { Redação }}$ dada pela Emenda Constitucional $\mathrm{n}^{\circ} 45$, de 2004) (grifo nosso).

Esse princípio, também conhecido como "persuasão racional", significa que, ao passo que o juiz tem a liberdade de formar seu livre convencimento com base nas provas que the foram apresentadas durante a instrução criminal, ele necessita fundamentar a decisão, isto é, explicitar os motivos que o levaram a chegar à determinada conclusão, sob pena de nulidade.

Lopes Jr., como sempre assertivo, contribui para o tema:

Nesse contexto, a motivação serve para o controle da racionalidade da decisão judicial. Não se trata de gastar folhas e folhas para demonstrar erudição jurídica (e jurisprudencial) ou discutir obviedades. O mais importante é explicar o porquê da decisão, o que o levou a tal conclusão sobre a autoria e materialidade. A motivação sobre a matéria fática demonstra o saber que legitima o poder, pois a 
pena somente pode ser imposta a quem - racionalmente - pode ser considerado autor do fato criminoso imputado ${ }^{27}$.

Seguindo este raciocínio, Gonçalves alerta sobre a fundamentação deficiente:

Tal deficiência é nítida quando o juiz utiliza argumentos genéricos, sem apontar nos autos as provas específicas que o levaram à absolvição ou condenação ou ao reconhecimento de qualquer circunstância que interfira na pena. Não pode o juiz se limitar a dizer, por exemplo, que a prova é robusta e, por isso, embasa a condenação. Deve apontar especificamente na sentença quais são e em que consistem estas provas $^{28}$.

Cumpre destacar a sutil diferença entre motivar e fundamentar a decisão. Segundo Giacomolli, referido por Di Gesu:

A fundamentação explica a preferência, a escolha de uma determinada versão, e não a de outra. Há fundamentação quando há justificação racional da decisão. A motivação, por sua vez, explicita quais as bases fáticas e/ou de direito que permitem a fundamentação, isto é, o entendimento acerca da tomada da decisão ${ }^{29}$.

O referido artigo constitucional faz menção, ainda, ao princípio da publicidade do julgamento e dos atos judiciais. Assim, via de regra, podem ser acompanhados por qualquer pessoa, como forma de garantir a legitimidade e eficiência do Poder Judiciário ${ }^{30}$. Excepcionalmente, a Constituição permite a restrição da publicidade dos atos processuais, como dispõe também o artigo $792, \S 1^{\circ}$, do CPP:

Se da publicidade da audiência, da sessão ou do ato processual, puder resultar escândalo, inconveniente grave ou perigo de perturbação da ordem, o juiz, ou o tribunal, câmara, ou turma, poderá, de ofício, ou a requerimento da parte ou do Ministério Público, determinar que o ato seja realizado a portas fechadas, limitando-se o número de pessoas que possam estar presentes.

27 LOPES JÚNIOR, 2014, p. 155.

28 GONÇALVES; REIS, 2018, p. 72.

29 GIACOMOLLI, Nereu José. A aproximação à garantia da motivação das decisões criminais: aspectos jurisprudenciais. Revista Ibero-Americana de Ciências Penais, 2005. p. 72 apud DI GESU, 2019, p. 76.

NUCCI, 2017, p. 64 


\subsection{Sistemas processuais penais}

Além da análise dos princípios constitucionais do processo penal, se torna mister para o desenvolvimento do presente trabalho, uma breve análise dos sistemas processuais penais e a adequação do processo penal brasileiro em relação a estes, ainda que não seja tema central.

Miranda Coutinho define sistema como sendo um "conjunto de temas jurídicos que, colocados em relação por um princípio unificador, formam um todo orgânico que se destina a um fim"31 Com relação aos sistemas processuais penais, a maior parte da doutrina afirma que seriam três: Sistema inquisitorial, sistema acusatório e sistema misto.

Historicamente, o sistema acusatório predominou na democracia grega e na Roma clássica, enquanto o sistema inquisitorial foi típico do Direito canônico e da Inquisição na era medieval. Assim, observa-se que o Estado democrático de direito se aproxima mais do modelo acusatório, enquanto regimes autoritários costumam flertar com o modelo inquisitivo ${ }^{32}$. Entretanto, a substituição de um sistema pelo outro, durante os séculos XII e XIV, se deu, basicamente, devido à incapacidade das partes de conter a criminalidade com a persecução penal sendo realizada por particulares, cabendo ao Estado assumir esta função ${ }^{33}$.

Assim sendo, Nucci tece alguns comentários sobre o histórico do sistema inquisitivo:

Esse sistema foi utilizado com sucesso em parte da Idade Média para combater os abusos cometidos pelos senhores feudais e pela aristocracia em detrimento de vassalos e pessoas pobres. Diante disso, os reis podiam enviar os juízes inquisidores, em seu nome, com poder suficiente para se voltar contra os ricos,

31 COUTINHO, Jacinto Nelson de Miranda (Coord.). O papel do novo juiz no processo penal. Crítica à Teoria Geral do Direito Processual Penal. 2001. p. 16.

AROCA, Juan Montero. Principio del proceso penal. Una explicación basada en la razón. Valência: Tirant lo Blanch, 1997. p. 25 apud DI GESU, 2019, p. 25.

33 LOPES JÚNIOR, 2014, p. 67. 
autores de delitos graves, que não podiam ser tratados com absoluta igualdade. Aliás, aplicava-se a ideia de isonomia - tratar desigualmente os desiguais ${ }^{34}$.

Nesse contexto, o sistema inquisitorial é caracterizado pela concentração da atividade acusatória e julgadora em uma mesma pessoa, isto é, o juiz. Dessa forma, compromete a sua imparcialidade, pois fica ligado psicologicamente ao resultado da demanda, uma vez que ao mesmo tempo que é responsável por iniciar a ação penal, deve colher e analisar as provas que servirão de base para a sentença ${ }^{35}$. Nas palavras do professor Aury: "É da essência do sistema inquisitório um "desamor" total pelo contraditório",36.

Além disso, é característico desse sistema, a prisão como regra, o procedimento sigiloso e predominantemente escrito, bem como o modelo de prova tarifada, que determinava uma hierarquia na valoração das mesmas, no qual a confissão do réu figurava como a rainha das provas.

Sobre esse tema, disserta Aury:

A estrutura do processo inquisitório foi habilmente construída a partir de um conjunto de instrumentos e conceitos (falaciosos, é claro), especialmente o de "verdade real ou absoluta". Na busca dessa tal "verdade real", transforma-se a prisão cautelar em regra geral, pois o inquisidor precisa dispor do corpo do herege. De posse dele, para buscar a verdade real, pode lançar mão da tortura, que se for "bem" utilizada conduzirá à confissão. Uma vez obtida a confissão, o inquisidor não necessita de mais nada, pois a confissão é a rainha das provas (sistema de hierarquia de provas). Sem dúvida, tudo se encaixa para bem servir ao sistema $^{37}$.

Em contraste, o sistema acusatório privilegia a oralidade, publicidade, a presunção de inocência e a liberdade como regra, o contraditório, além da separação entre o órgão acusador e o julgador,

$34 \quad$ NUCCI, 2017, p. 71.

35 LIMA, Renato Brasileiro de. Manual de processo penal: volume único. $4^{\mathrm{a}}$ ed. Rev., Ampl. e Atual. Salvador: JusPodivm, 2016. p. 12.

36 LOPES JÚNIOR, 2014, p. 67.

37 Ibid., p. 69. 
"contrapondo-se acusação e defesa em igualdade de condições, e a ambas se sobrepondo um juiz, de maneira equidistante e imparcial" ${ }^{38}$.

Outrossim, fica reservado ao juiz o papel de espectador quanto a produção de provas, além de garantidor das regras do jogo, sobretudo dos direitos e liberdades fundamentais. Portanto, a chamada "gestão da prova" no sistema acusatório é de responsabilidade das partes, ou seja, acusação e defesa $^{39}$. Há livre sistema de produção de provas e a confissão do réu não pode ser a única prova a embasar a condenação, devendo estar de acordo com as demais provas apresentadas e, na falta destas aplica-se o princípio In dubio pro reu.

A maior parte da doutrina entende que o modelo brasileiro é o misto. Isso porque, considerando que o processo penal brasileiro contemporâneo durante a fase pré processual, ou seja, o inquérito, predomina o sistema inquisitório e durante a fase processual prima o sistema acusatório, apresenta características de ambos os sistemas clássicos, e portanto, seria misto. Porém, Lopes Jr., na tentativa de fugir da maquiagem conceitual, defende que o Brasil adota o modelo (neo)inquisitorial e exclui o modelo misto da classificação clássica:

Ora, afirmar que o "sistema é misto" é absolutamente insuficiente, é um reducionismo ilusório, até porque não existem mais sistemas puros (são tipos históricos), todos são mistos. A questão é, a partir do reconhecimento de que não existem mais sistemas puros, identificar o princípio informador de cada sistema, para então classificá-lo como inquisitório ou acusatório, pois essa classificação feita a partir do seu núcleo é de extrema relevância ${ }^{40}$.

E justifica o autor:

Nesse contexto, dispositivos que atribuam ao juiz poderes instrutórios, como o famigerado art. 156, incisos I e II, do CPP, externam a adoção do princípio inquisitivo, que funda um sistema inquisitório, pois representam uma quebra da igualdade, do contraditório, da própria estrutura dialética do processo. Como 
decorrência, fulminam a principal garantia da jurisdição, que é a imparcialidade do julgador. Está desenhado um processo inquisitório ${ }^{41}$.

Por outro lado, Geraldo Prado, citado por Nucci, constata:

Se notarmos o concreto estatuto jurídico dos sujeitos processuais e a dinâmica que entrelaça todos os sujeitos de acordo com as posições predominantes nos tribunais (principalmente, mas não com exclusividade no Supremo Tribunal Federal), não nos restará alternativa salvo admitir, lamentavelmente, que prevalece, no Brasil, a teoria da aparência acusatória ${ }^{42}$.

\section{Ainda segundo Nucci:}

Não há nenhuma contradição, ao contrário, plena harmonia, para visualizar, no texto constitucional, relevantes princípios constitucionais de processo penal garantista, típicos do processo acusatório, ao mesmo tempo em que se encontra na mesma Constituição, a legitimação para a existência de preceitos investigatórios inquisitivos, demonstrando a natureza mista do nosso sistema de persecução penal ${ }^{43}$.

Assim, tendo em vista que a doutrina diverge em vários pontos, principalmente, sobre qual seria o princípio unificador do modelo brasileiro e, portanto, de qual sistema estaríamos mais próximos, caso se entenda que todo modelo contemporâneo é, de certa forma, misto, o que não falta são terminologias diferentes na tentativa de melhor caracterizar o modelo pátrio.

41 LOPES JÚNIOR, 2014, p. 75.

42 PRADO, GERALDO. Sistema acusatório. A conformidade constitucional das leis processuais penais. Rio de Janeiro: Lumen Juris, 2005. p. 195 apud NUCCI, 2017, p. 75.

$43 \quad$ NUCCI, 2017, p. 76. 


\section{A PROVA NO PROCESSO PENAL}

\subsection{Considerações sobre a prova no processo penal}

A origem do termo prova vem do latim probatio, "que significa ensaio, verificação, inspeção, exame, argumento, razão, aprovação ou confirmação"44. O ato de provar seria, então, em seu sentido amplo, “demonstrar a veracidade de um enunciado sobre um fato tido por ocorrido no mundo real" 45 .

No entanto, a doutrina usualmente entende que há três acepções para a palavra prova. Nessa esteira, Nucci ensina:

\footnotetext{
Há, fundamentalmente, três sentidos para o termo prova: a) ato de provar: é o processo pelo qual se verifica a exatidão ou a verdade do fato alegado pela parte no processo (ex.: fase probatória); b) meio: trata-se do instrumento pelo qual se demonstra a verdade de algo (ex.: prova testemunhal); c) resultado da ação de provar: é o produto extraído da análise dos instrumentos de prova oferecidos, demonstrando a verdade de um fato ${ }^{46}$.
}

No processo penal, o objeto da prova são, principalmente, os fatos delituosos, principais ou secundários. No entanto, dispensa-se a necessidade de fazer prova quanto aos fatos notórios, os impertinentes ou irrelevantes, ou impossíveis e os cobertos por presunção legal de existência ou veracidade $^{47}$. Da mesma forma, em virtude da presunção de que o juiz tem conhecimento do direito que deve ser aplicado ao caso concreto, dispensase prova acerca deste. Contudo, excepcionalmente, a parte deverá provar a vigência de normas municipais, estaduais, estrangeiras ou consuetudinárias, caso não sejam provenientes do local onde a causa está sendo julgada ${ }^{48}$.

Já a finalidade da atividade probatória no processo penal se revela como sendo o convencimento do juiz, que por sua vez, tem a incumbência

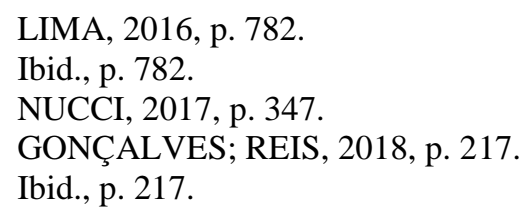


de reconstruir o momento histórico em análise, uma vez que não presenciou o fato, com vistas a decidir sobre a materialidade e autoria da infração ${ }^{49}$.

Cumpre ressaltar a assertiva de Di Gesu sobre a prova:

Inicialmente, partimos da premissa de que somente pode-se se chamar de "prova" aquela produzida sob o crivo do contraditório, a qual requer, necessariamente, a participação do destinatário final de seus efeitos, ou seja, do acusado. Com efeito, onde não houver contraditório, não há atos de prova, mas sim meros atos de investigação, os quais podem ser admitidos para absolver o acusado, mas não para condená- $-\mathrm{o}^{50}$.

\subsection{O mito da verdade na lógica processual penal}

Inicialmente, cumpre destacar a característica de atividade recognitiva do processo penal e seu aspecto temporal, chamado por Lopes Jr., de "paradoxo temporal ínsito ao ritual judiciário". Assim, o processo se revela como a tentativa de reconstrução de um fato histórico, com base em provas produzidas em um passado mais recente, para serem analisadas pelo juiz no presente, que por sua vez, deverá formar seu convencimento para formular a sentença que terá efeitos no futuro ${ }^{51}$.

$\mathrm{O}$ autor, destaca ainda que, historicamente, o processo penal sempre buscou a verdade real, aquela mais consistente. Dessa maneira, o mito da verdade real, ou seja, a crença de que a verdade efetivamente estava ao alcance do julgador, fruto da cultura inquisitiva, construiu uma ideia de processo que não respeitava limites, o lema era a verdade a qualquer custo. Para isso, legitimou diversas práticas abomináveis, como a tortura, comumente usada para obter a confissão, que nesta visão, seria a prova cabal da verdade ${ }^{52}$.

Noutro semblante, Di Gesu discorrendo sobre as palavras de Malatesta sobre a verdade:

Ibid., p. 409. 
Malatesta conceitua a verdade, em geral, como sendo a conformidade da noção ideológica com a realidade. Admite não coincidirem verdade e certeza, pois esta nada mais é que um estado subjetivo do espírito, o qual pode não corresponder à verdade objetiva. Justamente por ser subjetiva, pode-se ter certeza do que é falso; por vezes, pode-se duvidar do que é objetivamente verdadeiro.

Nesse contexto, a "verdade" produzida no processo, jamais se adequaria perfeitamente ao que aconteceu no plano real, ou seja, à verdade objetiva. O processo apenas seria capaz de produzir a chamada certeza judiciária, a verdade possível, aquela que alcança o mais alto grau de probabilidade de se aproximar da realidade ${ }^{53}$.

Sob o mesmo ponto de vista, Ferrajoli, citado por Lopes Jr. ensina:

Como explica Ferrajoli, a verdade processual não pretende ser a verdade. Não é obtida mediante indagações inquisitivas alheias ao objeto processual, mas sim condicionada em si mesma pelo respeito aos procedimentos e garantias da defesa. A verdade formal é mais controlada quanto ao método de aquisição e mais reduzida quanto ao conteúdo informativo que qualquer hipotética verdade substancial ${ }^{54}$.

Porém, Carnelutti, que inicialmente também se filiava à divisão entre verdade substancial (real) e verdade formal (processual) vai além e, desvelando o mito da verdade, passa a contestar, igualmente, a verdade formal, sustentando a impossibilidade do homem apreender o todo, abandonando a ideia de verdade de maneira geral $^{55}$.

Em suas palavras, traduzidas por Miranda Coutinho, Carnelutti inova dizendo:

A verdade de uma coisa nos foge até que nós não possamos conhecer todas as outras coisas e, assim, não podemos conseguir, senão um conhecimento parcial dessa coisa. E quando digo uma coisa, refiro-me também, a um homem. Em síntese, a verdade está no todo, não na parte; e o todo é demais para nós ${ }^{56}$.

53 AQUINO, José Carlos G. Xavier. A prova testemunhal no processo penal brasileiro. $5^{\mathrm{a}}$ ed. São Paulo: Letras Jurídicas, 2015. p. 27.

$54 \quad$ FERRAJOLI, Luigi. Derecho y Razón - teoría del garantismo penal. IBÁÑ̃E, Perfecto Andrés et al., (Trad.). 2a ed. Madrid: Trotta, 1997. p. 44 e ss apud LOPES JÚNIOR, 2014, p. 410.

55 CARNELUTTI, Francesco. Verità, dubbio certeza. In: Rivista di Diritto Processuale. v. XX. Padova: CEDAM - Casa Editrice Dott Antonio Milani, 1965 apud DI GESU, 2019, p. 89.

56 COUTINHO, Jacinto Nelson de Miranda. Glosas ao 'Verdade, Dúvida e Certeza' de Francesco Carnelutti, para os operadores do Direito. Disponível em: https://pt.scribd.com/document/240201544/Carnelutti-Verdade1-1-1. Acesso em: 18 abr. 2019. 
Contudo, Lopes Jr., que também sugere o abandono total da verdade no processo penal, explica que, na sua visão, Carelutti apenas substituí a "verdade" pela "certeza", que configura uma categoria igualmente insatisfatória. Por seu turno, propõe que a sentença seja vista como "um ato de convencimento formado em contraditório e a partir do respeito às regras do devido processo" ${ }^{, 57}$.

Assim, explica o autor:

\begin{abstract}
Se isso (a sentença) coincidir com a "verdade", muito bem. Importa é considerar que a "verdade" é contingencial, e não fundante. O juiz, na sentença, constrói pela via do contraditório - a "sua" história do delito, elegendo os significados que lhe parecem válidos, dando uma demonstração inequívoca de crença. O resultado final nem sempre é (e não precisa ser) a "verdade", mas sim o resultado do seu convencimento - construído nos limites do contraditório e do devido processo penal $^{58}$.
\end{abstract}

Com efeito, o ideal realmente seria utilizar a reconstrução do delito, promovida pelo processo penal, com vistas a trazer para a apreciação do juiz o fato, tal como ele ocorreu. Entretanto, a atividade retrospectiva não permite que isso aconteça, uma vez que se encontra balizada nas regras do devido processo legal, provenientes do sistema acusatório. Além disso, é formada por fatores complexos, como por exemplo as provas testemunhais, que por sua vez, sofrem influências da memória, emoção e das falsas lembranças dos sujeitos envolvidos nessa prova.

\title{
2.3. Das provas em espécie
}

O código de processo penal dispõe sobre alguns meios de prova, mas no geral, se entende que o rol apresentado por ele não é taxativo, admitindose todos os meios de prova que, direta ou indiretamente, possa servir para formar o convencimento do magistrado acerca da elucidação do fato, desde 
que não sejam ilícitos ${ }^{59}$. Assim, destacam-se o exame de corpo e delito e das perícias em geral, o interrogatório do acusado, a confissão, a oitiva do ofendido, a prova testemunhal, o reconhecimento de pessoas e coisas, a acareação, a prova documental e a busca e apreensão. Porém, apenas os meios que podem apresentar falsas memórias interessam para a presente exposição.

Sendo assim, o interrogatório é a oportunidade que o acusado tem de narrar sua versão dos fatos que lhe foram imputados, não só para apresentar uma tese defensiva ou confessá-los, mas para ajudar na elucidação dos fatos. Não obstante, o acusado tem, ainda, a possibilidade de permanecer em silêncio. $\mathrm{O}$ interrogatório judicial, se dá perante o juiz competente. Porém, há também o interrogatório na fase de inquérito, perante o delegado de polícia. Em ambos, a presença de seu defensor é indispensável ${ }^{60}$.

Relacionado a isso, encontra-se a confissão, também protagonizada pelo réu, que deve estar plenamente ciente de seus direitos, bem como deve ter completa liberdade e autonomia no ato de confessar. Além disso, a valoração dessa prova é condicionada a sua realização em juízo e sua conjugação com as demais provas colhidas, visto que, por si só, não pode justificar uma eventual condenação, atestando seu valor relativo ${ }^{61}$.

Já o ofendido, sempre que possível também deve prestar depoimento sobre os fatos. Porém, não tem o compromisso de dizer a verdade, atenuando o valor probatório de sua oitiva, que é tido como relativo. Desse modo, não se confunde com as testemunhas, pois não pode ser considerada um terceiro, estranho à relação processual. De certo, a despeito de Tourinho Filho $^{62}$ afirmar que o Estado é sujeito passivo constante ou formal de todo delito, já que o crime configura atentado à ordem jurídica, a vítima figura

\footnotetext{
59 GONÇALVES; REIS, 2018, p. 224.

60 NUCCI, 2017, p. 382.

61 LOPES JÚNIOR, 2014, p. 470.

62 TOURINHO FILHO, Fernando da Costa. Processo penal. 33 a ed. v. 3. Saraiva, 2011. p. 330 apud GONÇALVES; REIS, 2018, p. 252.
} 
como sujeito passivo do delito, ou seja, titular do bem jurídico lesado, considerando que as duas ideias não são excludentes ${ }^{63}$.

Ademais, nas palavras de Altavilla, "reconhecimento é o resultado de um juízo de identidade entre uma percepção presente e uma passada. Reconhece-se uma pessoa ou uma coisa quando, vendo-a, se recorda havêla visto anteriormente" ${ }^{\prime 64}$. Assim, é afirmar a identidade de uma pessoa ou a qualidade de uma coisa ${ }^{65}$. O procedimento de reconhecimento de pessoas está previsto no artigo 226 do Código de Processo Penal ${ }^{66}$, sendo aplicável, no que for cabível, ao reconhecimento de coisas. No entanto, na prática, o procedimento é comumente desrespeitado, ocasionando ilegalidades. Já o reconhecimento fotográfico e o fonográfico, apesar de não estarem previstos em lei, são admitidos pela doutrina e jurisprudência, devendo seguir o mesmo procedimento ${ }^{67}$.

Com relação a prova testemunhal, sem dúvidas, é uma das mais utilizadas no processo penal brasileiro. Sobre a origem da palavra testemunha, há divergências: enquanto uns entendem que vem da palavra testibus, que significa dar fé da veracidade de um fato, outros acreditam que vem de antesto ou antisto, que significa uma pessoa que vê diretamente um fato e conserva sua imagem ${ }^{68}$. Nas palavras de Gonçalves: “Testemunha é a

63 GONÇALVES; REIS, 2018, p. 252.

64 ALTAVILLA, Enrico. Psicologia Judiciária. $3^{\mathrm{a}}$ ed. MIRANDA, Fernando de. (Trad.). v. 1-2. Coimbra: Arménio Amado, 1981. p. 386 apud NUCCI, 2017, p. 454.

$65 \quad$ NUCCI, 2017, p. 454.

66 Art. 226. Quando houver necessidade de fazer-se o reconhecimento de pessoa, procederse-á pela seguinte forma:

I - a pessoa que tiver de fazer o reconhecimento será convidada a descrever a pessoa que deva ser reconhecida;

Il - a pessoa, cujo reconhecimento se pretender, será colocada, se possível, ao lado de outras que com ela tiverem qualquer semelhança, convidando-se quem tiver de fazer o reconhecimento a apontá-la;

III - se houver razão para recear que a pessoa chamada para o reconhecimento, por efeito de intimidação ou outra influência, não diga a verdade em face da pessoa que deve ser reconhecida, a autoridade providenciará para que esta não veja aquela;

IV - do ato de reconhecimento lavrar-se-á auto pormenorizado, subscrito pela autoridade, pela pessoa chamada para proceder ao reconhecimento e por duas testemunhas presenciais.

Parágrafo único. O disposto no $\mathrm{n}^{\mathrm{o}}$ III deste artigo não terá aplicação na fase da instrução criminal ou em plenário de julgamento.

67 LIMA, 2016, p. 960-961.

68 AQUINO, 2015, p. 38. 
pessoa física distinta dos sujeitos processuais chamada a juízo para prestar informações sobre fatos relacionados à infração, mediante assunção de compromisso de dizer a verdade" ${ }^{\circ 9}$.

Contudo, Aquino ressalta:

Se, a priori, toda pessoa tem capacidade natural para exercer a titularidade desse complexo de situações jurídicas (direitos, obrigações, sujeições etc.), que abarca o testemunho, é bem de ver que, se o sujeito não for capaz de perceber um acontecimento, conservá-lo ou transmiti-lo a outrem, em razão de seu desenvolvimento orgânico, ou em razão do seu estado mental, ou, ainda, se estiver enquadrado na limitação contida no art. 208 do Código de Processo Penal, não assumirá a função de testemunha propriamente dita, pois que, no nosso sistema vigente, ao seu depoimento não se deferirá compromisso ${ }^{70}$.

Lopes Jr., por oportuno, assevera:

Por fim, prevê o art. 214 a possibilidade de, antes de iniciado o depoimento, qualquer das partes contraditar a testemunha. Trata-se de uma forma de impugnar a testemunha, apontando os motivos que a tornam suspeita ou indigna. A contradita é um instrumento de controle da eficácia, pelas partes, das causas que geram a proibição (art. 207) ou impedem que a testemunha preste compromisso (arts. 208 e 206). Com essa impugnação, deverá o juiz questionar a testemunha sobre a veracidade do arguido, consignando tudo na ata da audiência ${ }^{71}$.

Finalmente, a acareação consiste em confrontar as declarações de duas ou mais pessoas que tenham sido conflitantes entre si, sobre algum ponto importante relacionado com a lide. Segundo as ideias de Hélio Tornaghi, Gonçalves discorre sobre a importância da acareação:

Embora se trate de providência probatória de emprego pouco usual, não se pode desprezar o valor psicológico da acareação, pois os sujeitos divergentes, se estiverem de boa-fé, poderão corrigir-se, instruir-se e retratar-se. Se, todavia, algum deles mentiu, é provável que demonstre hesitação ao ser confrontado ${ }^{72}$.

GONÇALVES; REIS, 2018, p. 256.

AQUINO, 2015, p. 110

LOPES JÚNIOR, 2014, p. 480.

TORNAGHI, Hélio. Instituições de processo penal. $2^{\mathrm{a}}$ ed., v. 4. Saraiva, 1977. p. 126127 apud GONÇALVES; REIS, 2018, p. 273. 


\subsection{Particularidades da prova testemunhal}

Conforme ensina Aquino: "É através do testemunho que a testemunha, ao depor, manifesta suas percepções sensoriais imediatas, recebidas fora do processo sub judice, sobre um dado objetivo pretérito, com o fim de prova" ${ }^{73}$. Nesse sentido se estabelecem críticas à objetividade no tratamento da testemunha, pois, apesar desta se expressar acerca de um dado objetivo e não figurar como parte, não há como acreditar que "aquilo que está sendo dito é isento de qualquer interesse ou paixão"74.

Dessa forma, ainda que não se examine a influência das falhas na memória, se constata a fragilidade dos testemunhos devido a carga de subjetividade que estes carregam. Sobre tal ponto, Di Gesu afirma:

A credibilidade da prova testemunhal dependerá do contexto probatório e de quanto persuadiu o julgador, pois, desde o abandono da tarifa probatória, nenhuma prova tem valor específico. Através da motivação da decisão, ter-se-á um controle se de fato o depoimento contribuiu ou não para o veredito ${ }^{75}$.

\subsubsection{Fases da formação do testemunho}

Nesse contexto, cumpre destacar as fases de formação do depoimento. De acordo com Vincenzo Perchinunno, existem três causas involuntárias que incidem no testemunho, quais sejam, a capacidade de impressão, de conservação e de expressão ${ }^{76}$.

A primeira está ligada ao conhecimento de um fato objetivo, ou seja, quando o sujeito constata uma modificação da realidade existente, direta (por meio de seus próprios sentidos) ou indiretamente (quando recebe a informação do fato por através de qualquer meio de comunicação). Além da percepção sensorial, destaca-se também a importância da atenção e

AQUINO, 2015, p. 40.

DI GESU, 2019, p. 94.

Ibid., p. 96.

PERCHINUNNO, Vincenzo. Limiti soggettivi della testimonianza nel processo penale.

Milano: Giuffrè, 1972. p. 33 apud AQUINO, 2015, p. 55. 
compreensão sobre o fato, que por sua vez, está intimamente relacionada com o estado de espírito do sujeito no momento deste ${ }^{77}$.

Seguindo essa linha de pensamento, Aquino ensina:

Essa tomada de posse é possível graças aos nossos sentidos: a audição, a visão, o gosto, o olfato etc. Os dois primeiros sentidos, sem sombra de dúvida, são, para o processo penal, os de maior utilidade, uma vez que são mínimas as possibilidades de aproveitamento das sensações apreendidas pelos demais. [...] Ao lado desses fatores pessoais que podem desfigurar a realidade de um acontecimento, existem outros, de natureza externa, que podem vir a influenciar a percepção da testemunha. Assim, por exemplo, as condições do tempo (neblina, chuva, etc.), os sons (ruídos de trânsito, rádio, enfim, a poluição sonora em geral) podem fazer com que a testemunha perceba erroneamente o que viu ou ouviu ${ }^{78}$.

Ato contínuo, o autor aborda a segunda fase, a conservação do conhecimento percebido, que se relaciona com a capacidade de reconstruir mentalmente fatos anteriores, por meio da fixação. Esse mecanismo só é possível devido a memória, definida pelo professor Sérgio Marcos de Moraes Pitombo como "uma faculdade humana sensorial, cognitiva interna, que se coloca no plano orgânico-mental e atua na capacidade de reviver os acontecimentos" 79 .

Essa fase se revela especialmente delicada, posto que ocorre inteiramente no âmbito interno do sujeito. Há que se pesar que a capacidade de gravação na memória varia de pessoa para pessoa e, não raro, esse processo apresenta falhas. Além disso, assim como na percepção do fato, os fatores externos e o estado de espírito do sujeito também podem influenciar a memória e o mecanismo da conservação.

Nesse ponto, cumpre destacar a forma como a percepção pode interferir na aquisição da memória sobre determinado fato. $\mathrm{O}$ mundo exterior é percebido por meio da atividade sensorial humana, que além de variar entre os indivíduos, muda de acordo com o estado de espírito destes.

\footnotetext{
$77 \quad$ AQUINO, 2015, p. 57-65.

78 Ibid., p. 56-57.

79 PITOMBO, Sérgio Marcos de Moraes. (conceito de aula) apud AQUINO, 2015, p. 70 -
} 
Logo, duas pessoas que presenciaram uma mesma cena, não necessariamente irão se recordar dela da mesma forma, uma vez que podem ter percebido-a de maneira distinta. Além disso, o esquecimento, fenômeno natural, fisiológico e adaptativo do ser humano atua sobre a memória, impedindo ou dificultando o acesso a certas lembranças.

Nessa linha de pensamento, se faz imperioso reproduzir as observações de Kretschmer:

\begin{abstract}
Nossas imagens-lembranças não existem no nosso cérebro em estado de provas ou de clichês fotográficos, prontos a serem reproduzidos estereotipadamente, toda vez que delas necessitamos. O que fica na memória, algum tempo após a realização da cena, são alguns vestígios de impressões óticas, acústicas e táteis que, apenas nascidas, logo se confundem com elementos de representações anteriores, provenientes de outras fontes. Quando se pede, num dado momento, a uma pessoa para fazer o relato de suas impressões concernentes a certo acontecimento, ela tende sempre a misturar, à sua narrativa, elementos outros colhidos em diversas fontes, e o faz involuntariamente, inconscientemente convencida de que só diz a verdade, a verdade estrita, evocando somente lembranças cuja exatidão poderia até jurar ${ }^{80}$.
\end{abstract}

Por fim, a fase da expressão do conhecimento, que acaba por representar uma das mais importantes, pois é quando a prova testemunhal se materializa, isto é, quando aquele fato que foi percebido e conservado pela testemunha, alcançará seu destinatário final, o juiz. Por oportuno, Silva Melero afirma: "A testemunha não é um mero narrador de fatos, mas sim de experiências" $"$.

Com o propósito de desempenhar corretamente esta atividade, tem que se ter atenção com relação à linguagem empregada, pois esta precisa ser compreensível, de modo que consiga representar e expressar seu objeto. Nesta esteira, Mira Y López acrescenta:

[...] basta dar um objeto qualquer, banal, a uma pessoa , deixá-la que o examine e pedir-lhe que no-lo descreva, para que nós, sem ver o objeto, cheguemos a uma compreensão do mesmo bem diferente de sua realidade, E isso simplesmente 
porque o indivíduo não acertou em transportar para nós em palavras tudo quanto percebeu; é uma aptidão pouco frequente a que permite descrever bem ${ }^{82}$.

Tão importante quanto o que foi exposto, é o alerta de Aquino sobre o artigo 215 do Código de Processo Penal ${ }^{83}$ :

Tal se faz necessário a fim de que o juiz não conduza consciente ou inconscientemente os depoimentos testemunhais, uma vez que se ele não tomar a devida cautela isso pode ocorrer, pois o ato de depor não se consubstancia numa simples narrativa do depoente, mas se configura num ato complexo que se traduz numa atividade psicofísica daquele que colhe o depoimento e físico-psíquica daquele que depõe, de modo que uma atividade pode influenciar a outra ${ }^{84}$.

\subsubsection{Cross examination}

A reforma processual penal (Lei $\left.\mathrm{n}^{\circ} 11.690 / 08\right)$, deu mais um passo no sentido do sistema acusatório, ao modificar a sistemática da colheita da prova testemunhal, alterando a redação do artigo 212 do Código de Processo Penal ${ }^{85}$, que passou a ser a seguinte:

As perguntas serão formuladas pelas partes diretamente à testemunha, não admitindo o juiz aquelas que puderem induzir a resposta, não tiverem relação com a causa ou importarem na repetição de outra já respondida.

Logo, abandonamos o sistema presidencialista, no qual as perguntas das partes eram feitas ao juiz que, posteriormente, indagava as testemunhas. No entendimento de Di Gesu, essa metodologia representava um claro resquício inquisitorial e explica:

Pior do que a lei exigir que o magistrado ouvisse a pergunta, reformulasse para, posteriormente, inquirir a testemunha, "filtrando" ou interpretando aquilo que foi dito por ela, o era o fato de o juiz questionar o depoente em primeiro lugar e,

82 LÓPEZ, Mira Y. Manual de psicologia jurídica. Rio de Janeiro: Ed. Agir, 1955. p. 180 apud AQUINO, 2015, p. 72.

Art. 215. Na redação do depoimento, o juiz deverá cingir-se, tanto quanto possível, às expressões usadas pelas testemunhas, reproduzindo fielmente as suas frases.

$84 \quad$ AQUINO, 2015, p. 80.

85 Antiga redação do artigo 212, CPP: “As perguntas das partes serão requeridas ao juiz, que as formulará à testemunha. O juiz não poderá recusar as perguntas da parte, salvo se não tiverem relação com o processo ou importarem repetição de outra já respondida". 
depois de satisfeito, passar a palavra à acusação e defesa, as quais, pelo sistema acusatório, devem gerir a prova ${ }^{86}$.

Sendo assim, atualmente, a gestão da prova testemunhal se encontra, efetivamente, a cargo da acusação e da defesa, cabendo ao juiz um papel subsidiário, de fiscalizador, buscando apenas adequar a atuação das partes aos limites legais e ao caso penal ${ }^{87}$. A testemunha será inquirida diretamente pela parte que a arrolou e, em seguida, caso haja interesse, deverá responder as perguntas da parte contrária, prestigiando o contraditório.

Conquanto, o papel do magistrado não se resume ao de garantidor legal na colheita da prova, papel esse de suma importância, pois ao vedar as perguntas sugestivas às respostas, pode reduzir a incidência de falsas memórias. Assim, o parágrafo único deste artigo estabelece, ainda, que o juiz poderá complementar a inquirição sobre os pontos não esclarecidos, após a manifestação das partes.

Com efeito, essa metodologia não representa uma completa inovação no processo penal, na realidade, se aproxima dos sistemas de cross examination, existente nos Estados Unidos e esame incrociato $^{88}$, proveniente da Itália. Entretanto, se diferencia do primeiro, visto que prevê a possibilidade de inquirição do juiz, enquanto no cross examination clássico, esta é função exclusiva das partes. Semelhantemente, se diferencia do modelo italiano, que permite uma espécie de "tréplica" pela parte de iniciou a inquirição, após o contraditório, possibilidade não prevista pela lei brasileira. 


\section{RELAÇÃO ENTRE O DIREITO E A PSICOLOGIA}

\subsection{A interseção do Direito e da Psicologia: A Psicologia Jurídica}

A ciência do direito possui a facilidade de se relacionar com diversas outras ciências humanas, uma vez que abrange diversos aspectos da vida e do ser humano. Durante todo o seu desenvolvimento, se fez explícita sua proximidade com a filosofia, sociologia e antropologia, conforme essas áreas foram, por si próprias, se estruturando. No que diz respeito a psicologia, não foi diferente.

No entanto, a interdisciplinariedade do direito não se encerra nas ciências humanas, se estendendo ainda para as ciências biológicas. É inegável a influência da medicina na prática forense, tanto é a importância dos estudos de medicina legal. Além disso, também merecem destaque as contribuições do ramo da psiquiatria, uma vez que, antes dos psicólogos, os psiquiatras já eram responsáveis pelos laudos periciais.

Nesse contexto, acredita-se que os hebreus foram os primeiros a utilizarem as avaliações médico-legais, que tinham lugar nos casos de anulação de casamento, esterilidade, impotência e homicídio ${ }^{89}$. No Brasil, o primeiro diagnóstico médico-legal de inimputabilidade se deu somente na década de 1920, no caso de Febrônio Índio do Brasil ${ }^{90}$.

Assim, a psiquiatria iniciou sua cooperação na prática forense devido à necessidade de avaliar a autonomia do indivíduo e sua capacidade de autodeterminação, bem como estabelecer os limites de sua responsabilidade $^{91}$. Hoje, a psicologia também se faz presente no direito na medida em que também estuda sobre o comportamento humano. Enquanto

89 PACHECO; SILVA A.C. Psiquiatria clínica e forense. São Paulo Renascença. 1951 apud SERAFIM, Antonio de Pádua; SAFFI, Fabiana. Psicologia e práticas forenses. Barueri: Manole, 2012. p. 2.

90 RIGONATTI S.P.; BARROS E.L. Notas sobre a história da psiquiatria forense, da antiguidade ao começo do século XX. São Paulo: Vetor, 2003. p. 17-22 apud SERAFIM, 2012, p. 4.

SERAFIM, 2012, p. 4. 
o direito se preocupa em regulá-lo porque o vê como fato, a psicologia se esforça para entendê-lo porque o vê como consequência.

A ciência do direito, tem como objeto de estudo o fenômeno jurídico contextualizado no tempo e no espaço, ou seja, estuda o direito positivo como experiência efetiva ${ }^{92}$. Enquanto o Direito seria um fato ou fenômeno histórico-social que regula a convivência ordenada e solidária dentro de uma sociedade ${ }^{93}$.

Por outro lado, a ciência da psicologia, consideravelmente mais recente que a ciência do direito, segundo Antonio de Pádua Serafim "se configura como a ciência que estuda a relação do funcionamento mental (funções e estruturas psicológicas) e sua expressão no comportamento" ${ }^{94}$. E complementa "A possibilidade de observar, descrever, analisar e predizer como uma pessoa percebe, sente, analisa e decide ação se reveste de equação complexa de multifatorialidade, representando assim a matéria da psicologia enquanto ciência" ${ }^{95}$.

Surge então, a psicologia jurídica como sendo a interface comum entre o direito e psicologia. Miguel Clemente define a disciplina como "o estudo do comportamento das pessoas e dos grupos enquanto têm a necessidade de desenvolver-se dentro de ambientes regulados juridicamente, assim como da evolução dessas regulamentações jurídicas ou leis enquanto os grupos sociais se desenvolvem neles" ${ }^{\prime 96}$. Nesse sentido, observa-se que essa relação é uma eterna via de mão-dupla. Partindo do pressuposto de que o objeto de estudo é mutável, ou seja, o ser humano e seu comportamento, ambas as ciências estão em constante desenvolvimento e sofrem influências mútuas durante esse processo.

\footnotetext{
92 REALE, 2002, p. 17.

Ibid., p. 2.

SERAFIM, 2012, p. 4.

Ibid., p. 4.

CLEMENTE, M. (Coord.). Fundamentos de la psicología jurídica. Madrid: Pirâmide, 1998. p. 25 apud TRINDADE, Jorge. Manual de Psicologia Jurídica para operadores do direito. Porto Alegre: Livraria do Advogado, 2009. p. 24.
} 
Nesse sentido, inspirado pelas ideias de Sandra L. Ferreira, Alvino Augusto de Sá conclui:

Depreende-se, pois, das colocações de Sandra L. Ferreira que a interdisciplinaridade não é uma soma de conhecimentos, que se completam, de forma a possibilitar um conhecimento mais amplo do fenômeno. Seria antes uma interdependência de conhecimentos, de tal sorte que cada um deles, isoladamente, não pode se sustentar como via de acesso a esse fenômeno. Uma interdependência que é dinâmica e se abre sempre a novas descobertas ${ }^{97}$.

Contudo, no cenário atual, ainda é negada à psicologia jurídica o status de ciência autônoma. Inclusive, o referido autor assevera que, apesar da proximidade entre as duas áreas, a psicologia jurídica desempenha, atualmente, um papel restrito de disciplina auxiliar ao direito e à administração da justiça ${ }^{98}$. Até porque, é considerada uma área ainda em construção e que, de certa forma, encontra resistência tanto por parte dos juristas quanto dos psicólogos.

Além disso, Trindade assinala:

Há aqueles que continuam a afirmar a impossibilidade da formulação psicojurídica, alegando que direito e psicologia pertencem a mundos diferentes: a psicologia, ao mundo do ser, o direito, ao mundo do dever-ser; a psicologia assentada na relação de causalidade, o direito, no princípio da finalidade ${ }^{99}$.

De todo modo, Muñoz Sabaté acredita que a psicologia jurídica pode ser útil tanto na produção legislativa, quando na organização do sistema de administração da justiça $^{100}$.

$97 \quad$ FAZENDA, Irani. Práticas interdisciplinares na escola. $4^{\mathrm{a}}$ ed. São Paulo: Cortez, 1997. p. 35 apud SÁ, Alvino Augusto de. Criminologia clínica e psicologia criminal. São Paulo: Editora Revista dos tribunais, 2007. p. 177.

98 CLEMENTE, 1998, p. 25 apud TRINDADE, 2009, p. 24.

99 TRINDADE, 2009, p. 23.

100 MUNOZ SABATE, L. et al. Introducción a la psicologia jurídica. México: Editorial Trillas, 1980. apud TRINDADE, 2009, p. 25. 


\section{2. Áreas em que a Psicologia Jurídica influencia a aplicação do Direito}

A psicologia jurídica desempenha um importante papel nas mais diversas áreas de atuação do Direito, principalmente na rotina da prática forense, no tocante à realização de perícias. Cumpre destacar o trabalho feito nas varas cíveis, do trabalho e nas criminais e de execução.

A contribuição da psicologia para o Direito Civil é vasta e complexa, envolvendo perícias psicológicas, assistência técnica, formação e rompimento de vínculo familiar, alienação parental, reconhecimento de paternidade, guarda, interdição, sucessão, adoção, entre outros. Nesse ponto, se evidencia sua participação no que diz respeito ao Direito de Família, uma vez que este lida diariamente com conflitos emocionais, recheados de subjetividade. Assim, a psicologia jurídica atua "propiciando maior compreensão da personalidade dos atores envolvidos, do desenvolvimento da dinâmica familiar e social, dos novos contornos e arranjos familiares"

Cumpre salientar a importância da psicologia jurídica nos casos de alienação parental, em que o psicólogo, assim como o operador do direito, devem estar preparados para reconhecer e mediar a lide, com vistas a minimizar os efeitos negativos provocados nas crianças, que acabam sendo afetadas e envolvidas no conflito de seus genitores. A título de exposição, o conceito de alienação parental segundo o psiquiatra Richard Gardner:

\footnotetext{
A alienação parental consiste em programar uma criança para que ela odeie um de seus genitores sem justificativa, por influência do outro genitor com quem a criança mantém um vínculo de dependência afetiva e estabelece um pacto de lealdade inconsciente ${ }^{102}$.
}

101 FIORELLI, José Osmir; MANGINI, Rosana Cathya Ragazzoni. Psicologia jurídica. $9^{\mathrm{a}}$ ed., Rev. e Atual. São Paulo: Atlas, 2018. p. 288.

Ibid., p. 310. 
Outro ponto que merece destaque é a avaliação psiquiátrica e/ou psicológica necessária nos casos de interdição, com o propósito de apurar a incapacidade do indivíduo de exercer os atos da vida civil. Sobretudo após o advento do estatuto da pessoa com deficiência, que alterou o Código Civil para considerar relativamente incapaz apenas "aqueles que, por causa transitória ou permanente, não puderem exprimir sua vontade" $" 103$, reservando a incapacidade absoluta somente para os menores de 16 anos. Assim, a avaliação deve ser cautelosa e específica com vistas a garantir a autonomia das pessoas com deficiência.

Já o Direito do Trabalho que, nas palavras do autor Maurício Godinho pode ser definido como:

[...] complexo de princípios, regras e institutos jurídicos que regulam a relação empregatícia de trabalho e outras relações normativamente especificadas, englobando, também, os institutos, regras e princípios jurídicos concernentes às relações coletivas entre trabalhadores e tomadores de serviços, em especial através de suas associações coletivas ${ }^{104}$.

Uma das características mais marcantes do Direito do Trabalho é o seu caráter protetivo, como forma de tentar reequilibrar uma relação jurídica, desigual por natureza, entre empregado e empregador. Dentro de uma sociedade capitalista, o empregado, isto é, quem vende sua força de trabalho, normalmente dispõe de menos recursos para fazer valer o seu direito frente ao empregador.

Nesse sentido, a relação trabalhista se configura como vertical e apresenta um alto grau de pessoalidade entre os envolvidos. Esse cenário é

\footnotetext{
103 Art. $4^{\text {o: }}$ São incapazes, relativamente a certos atos ou à maneira de os exercer: (Redação dada pela Lei $\mathrm{n}^{\circ} 13.146$, de 2015) (Vigência).

I - os maiores de dezesseis e menores de dezoito anos;

II - os ébrios habituais e os viciados em tóxico; (Redação dada pela Lei $\mathrm{n}^{\circ} 13.146$, de 2015) (Vigência).

III - aqueles que, por causa transitória ou permanente, não puderem exprimir sua vontade; (Redação dada pela Lei no 13.146 , de 2015) (Vigência).

IV - os pródigos.

104 DELGADO, Mauricio Godinho. Curso de direito do trabalho. $14^{\mathrm{a}}$ ed. São Paulo: LTr,
} 2015. p. 47. 
propício para a atuação da psicologia jurídica no enfrentamento dos conflitos existentes, na medida em que possuem aspectos de subjetividade, diretamente ligada à saúde mental dos envolvidos ${ }^{105}$.

Por fim, na seara criminal também são diversas as maneiras como a psicologia jurídica pode favorecer o exercício do direito. Em especial, os estudos da psicologia do testemunho, que exercem papel fundamental na incumbência de maximizar a qualidade dos depoimentos em juízo. Inclusive, na execução penal, os psicólogos integram a comissão responsável pela elaboração do exame criminológico, que está ligado não só ao programa de individualização da pena, como também à progressão de regime, entre outros. 


\section{FALSAS MEMÓRIAS NO CONTEXTO DO PROCESSO PENAL}

\subsection{Memória e a influência da emoção}

A memória é o que permite que o indivíduo guarde informações e estados de consciências passados, tais como ideias, sentimentos, conhecimento etc. Esta, “é desencadeada por sinais, informações recebidas pelos sentidos, que despertam a atenção. Se esta não acontecer, a informação não ativa a memória"106. Acredita-se que "todo conteúdo codificado e armazenado na memória ali permanece indefinidamente, a menos que exista dano físico em estruturas cerebrais. Isso, contudo, não assegura a recuperação desses conteúdos" ${ }^{\prime 107}$.

Importante observar que algumas memórias podem levar um tempo até se consolidarem, como as declarativas de longa duração. Tal afirmação pode ser justificada pela extensa sequência de processos bioquímicos necessários, considerando, ainda, as diversas partes cerebrais envolvidas nesses processos, como o córtex temporal, o hipocampo e a amígdala. Inclusive, algumas dessas estruturas também guardam relações com as emoções, que está intimamente ligada à memória ${ }^{108}$.

Nessa seara, acredita-se que os primeiros estudos científicos sobre a emoção começaram com Darwin, em sua obra A expressão das emoções no homem e nos animais. Nos dias de hoje, diversas áreas se dedicam ao estudo das emoções, com linhas de pesquisas que estabelecem uma relação complementar desta com a cognição. Nesses estudos, inclusive associados à memória, é comum a utilização da escala SAM (Self-Assesment Manikin), na qual a emoção é dividida em dois aspectos, alerta e valência. Ela permite que a memória possa ser classificada quanto a sua emocionalidade, o que

\footnotetext{
106 FIORELLI; MANGINI, 2018, p. 14.

107 Ibid., p. 17.

$108 \quad$ Ibid., p. 109.
} 
representa um enorme avanço na compreensão do fenômeno da distorção mnemônica $^{109}$.

Ainda segundo Stein, a título de exposição:

A valência constitui-se como uma variável contínua que vai do agradável (valência positiva) ao desagradável (valência negativa), passando por valores intermediários (valência neutra). $\mathrm{O}$ alerta refere-se a um espectro que varia de relaxante (baixo alerta) à estimulante (alto alerta) ${ }^{110}$.

Entretanto, devido à existência de várias linhas de pesquisas sobre as emoções e o emprego de diferentes metodologias, os resultados, por vezes, se mostram incongruentes entre si. Soma-se a isso, a divergência nos conceitos adotados pelas pesquisas, não só sobre a emoção, como também sobre características similares como o humor e o temperamento. Nesse contexto, "Atualmente, as emoções são definidas como coleções de respostas cognitivas e fisiológicas acionadas pelo sistema nervoso que preparam o organismo para comportar-se frente a determinadas situações"111. E são entendidas como um "estado intencional da mente"112 Ao passo que o temperamento e o humor são considerados conteúdos indeterminados, não intencionais e sem relação com eventos específicos ${ }^{113}$.

Apesar da carência de estudos mais assertivos sobre a influência da emoção na memória, de acordo com diversas pesquisas feitas até o presente momento, consolidou-se o entendimento de que eventos emocionais são mais lembrados que os não emocionais, porém essas lembranças não estão imunes a distorções. Portanto, o alto índice de memórias verdadeiras pode ser seguido pelo alto índice de memórias falsas ${ }^{114}$.

Brilhantemente, Di Gesu expõe suas ideias sobre o assunto:

109 STEIN, Lilian Milnitsky et al. Falsas memórias: fundamentos científicos e suas aplicações clínicas e jurídicas. [Edição Kindle]. Porto Alegre: Artmed, 2010. p. 91.

$110 \quad$ Ibid., p. 91.

111 Ibid., p. 87-88.

112 FRIJDA, N. H. Varieties of affects: Emotions and episodes, moods, and sentiments. In: EKMAN, P.; DAVIDSON, R. J. The nature of emotion. Oxford: Oxford University Press. 1994. apud STEIN, 2010, p. 93.

113 STEIN, Op. cit., p. 162.

114 Ibid., p. 88. 
Trazendo a questão para a seara criminal, colocamo-nos diante de mais um problema. O delito, sem dúvida, gera uma emoção para aquele que o testemunha ou que dele é vítima. Contudo, pelo que se pode observar, a tendência da mente humana é guardar a emoção do acontecimento, deixando no esquecimento justamente o que seria mais importante a ser relatado no processo, ou seja, a memória cognitiva, provida de detalhes técnicos e despida de contaminação (emoção, subjetivismo ou juízo de valor) ${ }^{115}$.

\subsection{Falsas memórias}

O fenômeno das falsas memórias pode ser entendido como a lembrança de fatos que não ocorreram na realidade ou, pelo menos, não da forma como se recorda, isto é, contendo distorções. Constitui o funcionamento normal da memória, não sendo considerado uma patologia. As falsas memórias "não são mentiras ou fantasias das pessoas, elas são semelhantes às $\mathrm{MV}$, tanto no que concerne a sua base cognitiva quanto neurofisiológica" 116 .

$\mathrm{O}$ interesse pelo estudo das falhas mnemônicas surgiu na Europa, no final do século XIX, e ao longo do século XX foi se desenvolvendo com contribuições de nomes como Theodule Ribot, Freud, Alfred Binet, Bartlett e Stern, entre outros. Não obstante os avanços alcançados entre as décadas de 70 a 90, principalmente com Loftus, ainda há um longo caminho a ser percorrido.

Uma das contribuições de Binet foi a diferenciação das falsas memórias entre sugeridas e autossugeridas, que depois passaram a ser conhecidas como espontâneas. As primeiras, são fruto de uma interferência externa, ou seja, uma informação proveniente do ambiente. Noutro giro, a espontânea decorre do próprio funcionamento da memória, a partir da distorção mnemônica em um processo interno ${ }^{117}$.

Acredita-se que é possível existir relatos que, apesar de apresentarem distorções de memória, contenham muitos detalhes, com informações 
coerentes e pareçam estar completos, dificultando a sua diferenciação das memórias verdadeiras. Nessa linha, ressalta Stein:

\begin{abstract}
Embora MV e FM possam apresentar algumas similitudes, estudos que comparam recordações de eventos vivenciados com eventos imaginados ou simulados, têm demonstrado um número maior de detalhes relatados nos primeiros do que nos últimos. Além disso, o tipo de informação relatada (p. ex., informação contextual, como a descrição do lugar ou a hora do dia; informação sensorial, tais como a descrição de sensações de calor ou de dor; informação afetiva, tais como a descrição de sentimentos de medo ou raiva) também têm sido associados à veracidade de uma lembrança ${ }^{118}$.
\end{abstract}

Importante mencionar que, apesar dos esforços de diversos estudos sobre as falsas memórias autobiográficas, que dizem respeito à história do indivíduo, são inúmeras as suas limitações metodológicas como:

1. O pesquisador raramente tem acesso ao evento concreto vivenciado pela pessoa, tornando difícil avaliar a acurácia das lembranças relatadas; 2. Existem inúmeras variáveis que podem afetar a memória (p. ex., significado pessoal do evento, emoção associada à lembrança, número de vezes que o episódio foi relatado), as quais não são passíveis de controle por parte do pesquisador; 3 . Diversas situações de vida ocorrem repetidamente (p. ex., festas, reuniões, passeios, etc), tornando nebulosa a distinção entre a memória para um evento específico daquela relativa a um conjunto de eventos semelhantes; 4. Os resultados de pesquisa sobre a MA, obtidos a partir de diferentes métodos de pesquisa, nem sempre são comparáveis entre si; 5 . Na prática, as lembranças que o indivíduo possui sobre seu passado se misturam com sua visão de si, suas crenças pessoais e com as crenças impostas por outras pessoas ${ }^{119}$.

Já as memórias implícitas, que se revelam mais duradouras e eficientes que as explícitas, se relacionam com os hábitos, habituações, sentimentos, habilidades motoras e sensoriais, condicionamentos e estereótipos. A evocação dessas memórias ocorre mais rapidamente, em um curto circuito nervoso, visto que se dá de modo não intencional ou consciente. Como resultado, de acordo com pesquisas embrionárias, é menor a probabilidade de se formarem falsas lembranças implícitas ${ }^{120}$.

\footnotetext{
118 STEIN, 2010, p. 195.

119 Ibid., p. 102.

120 SCHACTER, D. L. et al., Reductions in cortical activity during priming. Current Opinion in Neurobiology, 17(2), 2007b apud STEIN, 2010, p. 118-119.
} 
Por vezes, as distorções mnemônicas surgem como uma tentativa de completar lacunas existentes na memória. Nesse sentido, quanto mais coerente com a realidade e com o evento em foco for a informação distorcida, seja ela interna ou externa, mais provável que ela seja aceita como verdadeira. Sobre isso, alerta Di Gesu:

Na verdade, o juízo de probabilidade acaba por substituir as percepções reais, correspondendo à marcha de um processo lógico, a qual variará conforme a experiência do observador. Assim, mesmo que não tenhamos observado ou que a observação tenha sido distraída, há uma tendência, ao sermos perguntados, por exemplo, acerca de como estava um mendigo, de dizermos que estava sujo, remendado e bêbado ${ }^{121}$.

\subsubsection{Teorias explicativas do fenômeno das falsas memórias}

Existem três modelos teóricos que se propõem a explicar o fenômeno das falsas memórias, quais sejam, o Construtivista, o Monitoramento da Fonte e o Traço Difuso. No entanto, nenhum deles logrou êxito em esgotar os estudos sobre o tema, tampouco produziu explicações conclusivas, contendo, portanto, algumas limitações em suas bases teóricas.

Assim entende Stein:

Pensando nisso, os estudos têm avançado no sentido de explicar as bases cognitivas e neurofuncionais desse fenômeno. Não obstante, ainda há um longo caminho a ser percorrido, pois alguns mecanismos das FM permanecem como um campo a ser explorados ${ }^{122}$.

Em princípio, a Teoria Construtivista defende que há um único sistema de memória, que por sua vez, é construído baseado no significado, ou seja, na interpretação que a pessoa faz de determinado fato, não sendo memorizadas as informações específicas deste. Segundo ela, as falsas memórias advém de erros no processo de interpretação da informação. "Portanto, a memória específica e literal sobre a experiência vivenciada já 
não existe mais, apenas o entendimento e a interpretação que foi feita dela"123.

Dentro do paradigma construtivista, existe ainda a Teoria dos Esquemas, que acredita que a memória seria construída a partir de esquemas mentais. Esses, por sua vez, seriam "representações mentais que reúnem conceitos gerais sobre o que esperar em cada situação" ${ }^{\prime 24}$. As informações novas seriam interpretadas e armazenadas de acordo com os esquemas já existentes e a falha na memória ocorreria devido a algum erro nesse processo. De qualquer forma, também se filia a visão de memória unitária.

Não obstante, as principais críticas que se fazem a esse modelo são justamente sobre a característica unitária da memória e a perda das informações literais, uma vez que estudos realizados por Reyna e Kiernan ${ }^{125}$ demonstram que "as informações, tanto literais como as geradas a partir de interferências, foram recuperadas separadamente, evidenciando dissociação entre os diferentes tipos de memória"126. Logo, acredita-se não só na possibilidade de recuperar as informações literais, como na existência de mais de um sistema de memória.

Em seguida, buscando superar as vulnerabilidades apresentadas por esse modelo teórico, surgiram outras duas teorias que contrariam a primeira na medida que, em linha de princípio, rejeitam a ideia que de a memória seria um sistema único.

Nesse sentido, a Teoria do Monitoramento da Fonte afirma que as distorções mnemônicas são provenientes de um erro no julgamento da fonte

123 GALLO, D. A. et al., Reducing false recognition with criterial recollection tests: Distinctiveness heuristic versus criterion shifts. Journal of Memory and Language. 51, 2004 apud STEIN, 2010, p. 29.

124 POZO, J. I. Formação de conceitos artificiais. In: Teorias cognitivas da aprendizagem. Porto Alegre: Artmed, 1998 apud STEIN, 2010, p. 29.

125 REYNA, V. F.; KIERNAN, B. The development of gist versus verbatim memory in sentence recognition: Effects of lexical familiarity, semantic content, encoding instructions, and retention interval. Developmental Psychology, 1994. apud STEIN, 2010, p. 30.

126 STEIN, 2010, p. 30. 
de informação. Isso pode ocorrer, principalmente, devido às semelhanças entre os eventos ou a necessidade de recuperar rapidamente a fonte de uma informação ${ }^{127}$. Por exemplo, recordar uma informação que foi vista na televisão, como sendo uma experiência própria vivida.

A semelhança entre os eventos se relaciona com os eventos repetitivos, sobre isso:

Quando um evento acontece repetidas vezes, como na maioria dos casos de abuso sexual, as informações para a experiência são generalizadas e, a cada nova repetição, comparadas com as representações já armazenadas sobre o que esperar em cada situação. Essas experiências podem ser unidas em uma única memória a respeito dos eventos, por meio da elaboração de imagens mentais familiares. Nesse caso, distinguir informações específicas sobre um determinado evento torna-se mais difícil. Detalhes específicos, não familiares, são muitas vezes esquecidos ou atribuídos falsamente a experiências reais quando, na verdade, resultam da imaginação ${ }^{128}$.

A limitação desta teoria se revela no fato de que as falhas na memória seriam apenas quanto ao monitoramento da fonte e não uma distorção na memória propriamente dita. Além disso, há críticas quanto a recuperação da memória estando condicionada a fonte, uma vez que pesquisas experimentais demonstram que há uma dissociação entre a recuperação de memórias verdadeiras e falsas.

Por fim, a Teoria do traço difuso, em resumo, sugere que existem múltiplos traços de memória e divide esta em dois sistemas: memórias literais e de essência. Enquanto a primeira diz respeito aos detalhes específicos e superficiais de determinado evento, a segunda se verifica como a compreensão do significado do mesmo ${ }^{129}$. Tal teoria, representou uma inovação ao relacionar a intuição ao funcionamento cognitivo, "ao contrário do que teorias tradicionais preconizavam, o nosso processamento

\footnotetext{
127 STEIN, 2010, p. 31-32.

128 JOHNSON, M. K. et al., Source monitoring. Psychological Bulletin, 114, 1993. apud STEIN, 2010, p. 32.

129 BRAINERD, C. J.; REYNA, V. F. The science of false memory. New York: Oxford University Press, 2005 apud STEIN, 2010, p. 34.
} 
cognitivo busca caminhos que facilitem e agilizem a compreensão" ${ }^{\text {"130 }}$. Privilegiando, assim, os traços da memória de essência em detrimento dos traços da memória literal.

Dentro desse paradigma foram concebidos cinco princípios norteadores da Teoria do Traço Difuso: O primeiro e o segundo princípios estão diretamente ligados entre si, visto que versam sobre o armazenamento paralelo da informação e a recuperação independente da memória de essência e literal. O que significa dizer que, apesar de ambas corresponderem ao mesmo evento e serem processadas ao mesmo tempo, são armazenadas e podem ser recuperadas separadamente ${ }^{131}$.

Em seguida, cumpre destacar a seguinte síntese sobre o próximo princípio:

Já o terceiro princípio da TTD refere-se ao julgamento das informações quando expostos a tarefa de recordação ou reconhecimento. Brainerd, Reyna, Wright e Mojardin (2003) preconizam que haveria um julgamento da veracidade do traço de memória recuperado de tal forma que traços literais são recuperados corretamente por um processo de julgamento da identidade da informação, induzindo a uma rejeição da informação de essência (p. ex., lembro que comi um hambúrguer com queijo e não um cachorro quente, ainda que ambos sejam essencialmente lanches). No entanto, em alguns casos, a informação literal pode levar a uma recuperação de essência, especialmente quando há uma semelhança ou familiaridade entre as informações ${ }^{132}$.

O quarto princípio assevera que, uma vez que a memória de essência tende a permanecer mais estável ao longo do tempo em comparação com os traços literais, esses são mais suscetíveis a efeitos de interferência, seja espontânea ou sugerida.

Já o quinto princípio pode ser entendido como a capacidade de recuperação dos traços de memória pelos indivíduos de acordo com seu desenvolvimento. Nesse sentido: 
[...] crianças pequenas apresentam maior dificuldade de trabalhar com traços de essência do que com traços literais. No entanto, à medida que crescemos nos tornamos mais eficientes em utilizar estratégias de memória e, portanto, há um aumento na habilidade de lembrarmos uma informação tanto em termos de memória literal quanto em termos de memória de essência. Alguns estudos (Brainerd e Reyna, 1998) sugerem que a habilidade de recuperar traços literais decai com o avanço da idade ${ }^{133}$.

A despeito disso, três críticas foram formuladas para essa teoria. A primeira se revela na incapacidade de explicar os erros de julgamento da fonte para eventos distintos quanto aos traços literais. Já a segunda, alude para a dificuldade de análise dos casos de falsas memórias em experiências mais abstratas. Por último, a mais importante:

[...] questiona a divisão da memória em traços, ressaltando estudos em que há recuperação de detalhes perceptuais duradouros, fato esse que vai de encontro ao princípio de durabilidade dos traços literais, e de falsas recordações baseadas em aspectos semânticos e perceptualmente vívidos, fato que vai de encontro com o caráter difuso da teoria ${ }^{134}$.

Desse modo, a Teoria do Traço Difuso se configura como a mais complexa e, apesar de superar algumas lacunas deixadas pelas demais teorias, não elucida todos os questionamentos acerca das ocorrências das falhas na memória.

\subsubsection{Diferenças individuais na formação de falsas mnemônicas}

Os estudos indicam que diversos fatores influenciam nos processos mnemônicos, entre eles, técnicas de entrevistas, fatores situacionais do meio e do indivíduo, bem como as diferenças individuais de cada pessoa. Nesse contexto, atesta Stein:

Até o momento atual, a maior parte dos estudos sobre FM vêm sendo realizados com populações homogêneas e, principalmente, com a participação de estudantes universitários, o que indica uma menor preocupação com as diferenças

\footnotetext{
133 STEIN, 2010, p. 36.

134 LINDSAY, D. S.; JOHNSON, M. K. False memories and the source monitoring framework: Reply to Reyna and Lloyd (1997). Learning and Individual Differences, 12, 2000 apud STEIN, 2010, p. 37.
} 
individuais. Porém, Blair, Lenton e Hestie (2002) demonstraram que as pessoas diferem quanto à produção de FM entre si, e que isso é algo estável ao longo do tempo, ou seja, não se deve apenas às diferenças situacionais ${ }^{135}$.

Entretanto, os resultados das pesquisas da Psicologia Diferencial, ainda não são conclusivos a ponto de explicar como cada característica impacta na memória. O que se tem são testes iniciais que já apontam um caminho mas não podem ser considerados unânimes.

Sob esse enfoque, as análises apontam que alguns traços dissociativos de personalidade, podem levar as pessoas a não confiarem tanto em suas memórias e, como consequência, serem mais suscetíveis à distorções mnemônicas. Dentre esses traços, se encontra a ansiedade e o neuroticismo, que se revela "um traço estável de personalidade e que está ligado a uma tendência em experienciar emoções negativas e aflitivas"136. Por outro lado, não foram observadas diferenças significativas nas taxas de falsas memórias entre homens e mulheres, por exemplo.

Ademais, considerando as especificidades das crianças e dos idosos referentes às memórias de essência e literais, comparados com adultos saudáveis, de modo geral, as crianças tendem a ter menos falhas mnemônicas, enquanto os idosos apresentam uma taxa maior. Já com relação a experiências traumáticas vividas na infância:

Crianças expostas a traumas não apresentam alterações de memória durante essa etapa do desenvolvimento, porém, quando adultas, observa-se a presença de déficits mnemônicos que acabam por reduzir os índices de FM, se comparados com os de adultos que não sofreram trauma na infância ${ }^{137}$.

\subsection{Falsas memórias e a prova penal}

Tendo em mente a importância da prova testemunhal e do interrogatório da vítima, principalmente porque, não raro estes constituem 
único meio de prova aptos a embasar uma condenação no processo penal, é fundamental o estudo dos fatores que causam a fragilidade destas provas como, a subjetividade da testemunha, o nexo temporal entre o acontecimento e o depoimento e as distorções mnemônicas.

A subjetividade da testemunha, como já visto, pode estar ligada ao modo como o fato é percebido por ela, tendo em vista todas as condições externas e internas que interferem nesse processo. Porém, pode também ter relação com os fatores que a influenciam após a aquisição da memória sobre determinado evento até o efetivo depoimento sobre ele. Nesse contexto, destaca-se a bagagem sócio emocional do depoente, como seus preconceitos, valores, princípios e crenças arraigadas que interferem na sua percepção, bem como a tendência afetiva, ou seja, sua identificação emocional com umas das partes, sua capacidade de se imaginar no lugar dela $^{138}$.

Ponto importante, ainda, é o risco da sugestionabilidade da testemunha. Dependendo da linguagem e dos métodos utilizados pelo entrevistador, ele pode indiretamente causar a formação de uma falsa memória, como também, diretamente influenciar na resposta do depoente, que pode se sentir constrangido a corresponder às expectativas de resposta da pergunta feita. Soma-se a isso a sugestionabilidade que pode surgir pela ingerência da mídia, como discorre Di Gesu:

A mídia acaba por familiarizar - melhor dizendo, massacrar - a população com investigações policiais, com as decisões acerca de buscas e apreensões, prisões cautelares, concessões de liminares em habeas corpus, entre outras, induzindo-a sempre de forma parcial - pois apenas trechos são revelados - sem que se tenha conhecimento acerca dos autos, gerando um imenso grau de contaminação. Pelo conteúdo das matérias veiculadas na televisão, os réus dos delitos contra a vida, sem sombra de dúvidas, culpados ou inocentes, já foram condenados pelo Júri Popular, mesmo antes do término das investigações. E o grau de contaminação é tal que nem sequer o desaforamento solucionaria o problema ${ }^{139}$. 
Já o nexo temporal é um problema especialmente comum nos casos do tribunal do júri, em que o julgamento e os depoimentos em juízo podem ocorrer muitos anos, por vezes até uma década, após o fato delituoso. Se revela um elemento adverso ao testemunho, não só pela possibilidade do esquecimento afetar a memória e da formação de falsas lembranças, mas também dos aspectos ressaltados por Fiorelli:

Os efeitos dessa dissonância temporal entre a justiça e a vida corrente são marcantes sob os mais diversos aspectos; as emoções modificam-se; a memória pode ser aliada do delinquente e adversária da vítima ou vice-versa; a importância privada e social dos acontecimentos modifica-se com o passar do tempo - é conhecidíssima a volatilidade da memória pública, que se alimenta primordialmente das pílulas de lembranças dos noticiários ${ }^{140}$.

Observa-se que vínculos subjetivos e particularidades do depoente, muitas vezes são consideradas como fatores prejudiciais à credibilidade do testemunho, precipuamente quanto a dados objetivos. Tanto é que se a testemunha for parente do acusado, menor de 14 anos ou deficiente mental será considerada mera informante, isto é, não prestará o compromisso de dizer a verdade, assim como o ofendido e o acusado. Este último, inclusive tem o direito de permanecer em silêncio. Contudo, a subjetividade da testemunha e as falsas lembranças normalmente não são levadas em conta na valoração do testemunho. Apesar da possibilidade de afetarem todos os que depõem, o foco se mantém nas testemunhas, uma vez que estas prestam compromisso.

Nesse ponto, cumpre registrar a diferença entre falsas memórias e o falso testemunho ${ }^{141}$, na medida em que neste a testemunha deliberadamente mente sobre um fato, faz declaração que sabe não coincidir com a realidade, enquanto naquele a distorção no relato ocorre de forma não intencional, decorrente do funcionamento da memória. Fiorelli, ao citar as falsas

\footnotetext{
140 FIORELLI; MANGINI, 2018, p. 175.

141 CP, Art. 342. Fazer afirmação falsa, ou negar ou calar a verdade como testemunha, perito, contador, tradutor ou intérprete em processo judicial, ou administrativo, inquérito policial, ou em juízo arbitral: (Redação dada pela Lei nº 10.268, de 28.8.2001).
} 
lembranças, explica que "para aquele que depõe, a memória é percebida como real. Pode tratar-se não de um mero artifício para excusar (sic) a si ou a outrem de responsabilidade, mas de um mecanismo de defesa do ego" ${ }^{\prime 142}$.

Além disso, apesar da memória evocativa, "aquela verbalizada através da descrição do fato delituoso e de seu autor" ${ }^{\text {"143 }}$, exigir mais da memória do que o ato de reconhecimento, as distorções mnemônicas também se fazem presente neste, quando a pessoa compara uma memória passada com uma imagem no presente, seja pessoalmente ou por fotografia. Nessa linha de pensamento, Di Gesu afirma:

Com efeito, quanto mais repetida a percepção, mas complexa e mais precisa ela será. A exatidão da percepção e a capacidade de distinguir detalhes depende, geralmente, do conhecimento prévio acerca do objeto ou da pessoa a ser identificada.

No entanto, uma sólida percepção da coisa ou pessoa não isenta o reconhecimento de erros, isso porque outros elementos podem interferir no processo, como a sugestionabilidade e o erro de monitoramento da fonte. Dessa forma cumpre mencionar uma passagem da obra de Stein, que ilustra perfeitamente essa questão:

Chamado para fazer uma corrida, um taxista foi vítima de um assalto, no qual sofreu ferimentos, e foi levado ao hospital. O investigador do caso mostrou ao taxista, que ainda estava em fase de recuperação, duas fotografias de suspeitos. O taxista não reconheceu os homens apresentados nas fotos como sendo algum dos assaltantes. Passados alguns dias, quando foi à delegacia para realizar o reconhecimento dos suspeitos, ele identificou dois deles como sendo os autores do assalto. Os homens identificados positivamente eram aqueles mesmos das fotos mostradas no hospital. Os suspeitos foram presos e acusados pelo assalto. Ao ser questionado em juízo sobre seu grau de certeza de que os acusados eram mesmo os assaltantes, o taxista declarou: "eu tenho mais certeza que foram eles, do que meus filhos são meus filhos!". Todavia, alguns meses depois, dois rapazes foram presos por assalto em uma cidade vizinha, quando interrogados, confessaram diversos delitos, incluindo o assalto ao taxista ${ }^{144}$. 
Como visto, o caso acima retrata a hipótese da formação de uma falsa memória, a partir da sugestionabilidade externa - fotos de pessoas mostradas ao taxista logo após o assalto - e erro de monitoramento da fonte, pelo qual o taxista reconheceu os indivíduos porque já havia visto as fotos, porém achando que esta memória era do evento do assalto. Nesse âmbito, a prática do reconhecimento fotográfico, usualmente realizada em sede de delegacia, que consiste na apresentação de fotos de pessoas "fichadas" propicia a ocorrência de situações como a descrita. Na realidade, o mais indicado seria seguir o procedimento de reconhecimento de pessoas, no que couber, previsto pelo artigo 226 do Código de Processo Penal ${ }^{145}$.

Sobre o reconhecimento de pessoas em geral, à luz das ideias de Giacomolli, Di Gesu constata:

\begin{abstract}
Portanto, considerando que a função do reconhecimento é justamente dissipar qualquer dúvida acerca da participação do imputado do fato delituoso, deve revestir-se das formalidades legais. Ademais, o ideal recomendado por pesquisadores é que o condutor do ato de reconhecimento desconheça quem seja o suspeito, bem como que a vítima e/ ou testemunha presencial, se houver, diga, no momento do ato, o grau de certeza sobre a identificação, e não quando da documentação da ata ou certidão, pois o reconhecimento é invalidade quando se diz que o sujeito é "parecido" ou "bem parecido" com o réu (desde que não haja outras provas a incriminar o acusado, tais como, p. ex., a apreensão dos bens subtraídos em seu poder, um exame datiloscópico ou de DNA confirmando a autoria) ou então quando a descrição do envolvido não condiz com as características físicas do imputado $^{146}$.
\end{abstract}

Desse modo, o ato de reconhecimento, principalmente de pessoas, é um momento muito delicado e o ideal seria que fosse efetuado seguindo a risca tanto as regras estabelecidas pela lei, quanto às técnicas que, comprovadamente, reduzem a sugestionabilidade e, por conseguinte, as falhas mnemônicas.

Igualmente problemático, se revelam as condenações baseadas exclusivamente nos depoimentos dos policiais que efetuaram a prisão do

\footnotetext{
$145 \quad$ DI GESU, 2019, p. 158.

146 GIACOMOLLI, Nereu José. A fase preliminar do processo penal: crises, misérias e novas metodologias investigativas. Rio de Janeiro: Lumen Juris, 2011. p. 157-158 apud DI GESU, 2019, p. 161.
} 
autor do fato. Ainda que se considere que estes seriam testemunhas imparciais, ignorando o fato de que seu testemunho normalmente será no sentido de legitimar sua atuação, eles, por óbvio, também estão sujeitos à incidência de falsas memórias, essencialmente do tocante aos efeitos dos eventos repetitivos.

Estudos apontam que em eventos repetitivos a informação central é lembrada com mais facilidade que os detalhes específicos dos eventos. Além disso, os aspectos variáveis dos eventos que se repetem apresentam "mais incorreções e maior aceitação de informações falsamente sugeridas para esse tipo de informação" 147 , quando comparados a um evento único. Dessa maneira, não cabe dizer que os depoimentos que advém de eventos repetitivos, como as inúmeras prisões que as autoridades policiais efetuam em sua rotina, são despidos de validade, porém devem ser valorados com cautela, mormente no que se refere aos detalhes dos fatos.

\subsubsection{Famigerados casos de erros judiciais causados por falhas na memória}

Ainda que os estudos sobre as distorções na memória datem de séculos passados, casos recentes colocaram o tema em voga, principalmente porque relacionados com o julgamento de supostos crimes. É inegável a danosidade das falsas memórias para o processo penal, problema que se evidencia nos casos a seguir:

Em primeiro lugar, Stein, refere-se ao caso de Beth Rutherford ${ }^{148}$, norte-americana de 19 anos que, após começar a frequentar uma terapeuta, que utilizava técnicas de hipnose, recuperou lembranças de que era abusada sexualmente por seu pai, com a ajuda de sua mãe. Inclusive, que teria engravidado dele duas vezes e abortado. 
O caso se passou nos Estados Unidos, onde na década de 90 se proliferou esse tipo de terapia que consistia em recuperar memórias esquecidas por um longo tempo. Essa técnica acabou levando a produção de falsas memórias de abusos sexuais em muitos casos, que com efeito, foram parar no judiciário, inclusive culminando na condenação de diversas pessoas $^{149}$.

No caso de Beth, diversas circunstâncias acabaram por desmentir o suposto abuso, principalmente porque um exame pericial atestaram que esta ainda era virgem e nunca havia engravidado. Entretanto, isso não impediu as consequências desastrosas em sua vida e de seus familiares. Além de seu pai ter perdido o emprego na época das acusações, sua relação com ele e sua mãe ficou extremamente abalada durante esse período.

Podemos citar também, o caso da Escola Base de São Paulo (1994), exposto por Di Gesu ${ }^{150}$, em que duas mães de alunos da aludida escola, denunciaram os proprietários da mesma, em conjunto com professores e um casal de pais de outro aluno por abuso sexual infantil. Segundo uma das mães, o filho teria the contado que assistia filmes pornográficos, presenciava atos de relação sexual e praticava atos libidinosos, sendo fotografados no apartamento do referido casal.

No decorrer do inquérito aberto para investigar o caso, suscitou-se ainda a hipótese de uso de drogas e contaminação por HIV. Um exame pericial feito no menino atestou lesões corporais leves compatíveis com a prática de atos libidinosos, porém também compatíveis com patologias anoretais de causas naturais, sendo certo que o menino sofria de constipação intestinal. Já o exame toxicológico teve resultado negativo. Após três meses de investigações, com três delegados envolvidos no caso, o inquérito foi arquivado devido ausência de indícios contras os suspeitos. 
Contata-se diversos pontos problemáticos nesse caso. Acima de tudo, a falsa memória, provavelmente, formada pela maneira como a mãe entrevistou o filho sobre o suposto abuso, com viés altamente sugestivo. Além disso, o atropelo de diversas garantias dos acusados, bem como a atuação da mídia, que muitas vezes recebiam informações antes mesmo delas constarem nos autos do processo. Dessa forma, ganhou grande repercussão, gerando um caos na vida dos acusados, que preferiram se afastar, depois que depredaram e lançaram um coquetel molotov na escola e sofreram represálias em suas casas.

\subsubsection{Depoimento infantil e suas peculiaridades}

De acordo com Código de Processo Penal brasileiro, qualquer pessoa pode ser testemunha ${ }^{151}$, porém, o artigo 208 do referido diploma legal ${ }^{152}$, dispensa algumas pessoas da obrigatoriedade de prestar compromisso de dizer a verdade, entre elas, os menores de 14 anos. Porém, o depoimento infantil, seja como testemunha ou como vítima, pode ser tão confiável quanto o de adultos. Apesar de ser dotado de peculiaridades, caso seja obtido de forma cautelosa e adequada pelos operadores do direito, pode ser usado como importante meio de prova.

À luz desse tema, as palavras de Stein:

Em sua maioria, as crianças que testemunham estão envolvidas em situações de violência e seus relatos dizem respeito a lembranças de experiências muitas vezes traumáticas. Frequentemente, na ausência de outros indícios, o relato da criança torna-se a única evidência num processo criminal. Na verdade, a maior parte dos abusos e maus-tratos contra crianças não deixa vestígios em seus corpos e, nem sempre, resulta invariavelmente em danos psíquicos ${ }^{153}$.

Nesse contexto, imperioso se faz conhecer as especificidades e fragilidades do depoimento de crianças e adolescentes, tendo como objetivo

\footnotetext{
151 Art. 202. Toda pessoa poderá ser testemunha.

152 Art. 208. Não se deferirá o compromisso a que alude o art. 203 aos doentes e deficientes mentais e aos menores de 14 (quatorze) anos, nem às pessoas a que se refere o art. 206.

153 STEIN, 2010, p. 157.
} 
minimizar tanto a incidência de falsas memórias quanto a revitimização da mesma. Os esforços para que seu testemunho seja o mais preciso e fiel possível são essenciais não só para que o processo penal cumpra sua função mas, principalmente, para garantir sua proteção.

Uma das limitações é amnésia infantil, que reflete a ausência de memórias dos primeiros anos de vida (até aproximadamente três anos), diz respeito não só ao testemunho infantil, mas aos casos em que adultos depõem sobre fatos ocorridos em sua infância. Estudos demonstram que "embora as crianças tenham capacidade de recordação episódica desde muito cedo, as recordações não permanecem acessíveis até o desenvolvimento mais organizado da linguagem" ${ }^{, 154}$.

Assim, considerando crianças a partir dos três anos de idade, estudos afirmam que elas "são capazes de recordar e relatar, por longos períodos de tempo, quantidades substanciais de informação sobre eventos, sejam eles relativos a acontecimentos agradáveis e positivos ou estressantes e negativos" ${ }^{\prime 155}$. Todavia, há de se ter em mente a interferência que o longo transcurso de tempo entre o evento e o depoimento pode efetuar na memória.

Não obstante as fragilidades já mencionadas, sem dúvidas, um dos maiores reveses dos depoimentos infantis é a maior suscetibilidade das crianças a sugestionabilidade por parte do entrevistador. Segundo Schacter, esta "consiste na tendência de um indivíduo em incorporar informações distorcidas, oriundas de fontes externas, às suas recordações pessoais, sendo que essas informações podem ser apresentadas de forma intencional ou acidental $" 156$.

$154 \quad$ STEIN, 2010, p. 162.

155 PEZDEK, K.; TAYLOR, J. Memory for traumatic events for children and adults. In: M. L. Eisen et. al., Memory and suggestibility in the forensic interview. Mahwah: Lawrence Erlbaum, 2002 apud STEIN, 2010, p. 163.

156 SCHACTER, D. L. The seven sins of memory: Insights from psychology and cognitive neuroscience. American Psychologist, 54(3), 1999 apud STEIN, 2010, p. 167. 
Tal sugestionabilidade, como apontam diversos estudos, é fruto da interação de, basicamente, dois fatores, quais sejam, as características individuais da criança e contexto da entrevista, levando em conta os fatores sociais. Dentre os fatores individuais encontram-se os que se referem a faixa etária da criança ou a características subjetivas de cada uma.

Sob esse enfoque, percebe-se que crianças em idade pré-escolar são mais sugestionáveis em comparação com crianças mais velhas, adolescentes e adultos. O que não significa dizer que aderirão a qualquer sugestão externa, "Ao contrário, as crianças tendem a não aceitar falsa informação quando esta é muito diferente do contexto vivenciado ou testemunhado" ${ }^{\text {"157. }}$. Esse fato pode ser explicado por três aspectos: as crianças pequenas têm uma tendência maior a respeitar a autoridade do adulto e acatar suas sugestões, explícitas ou implícitas; têm maior dificuldade na recordação livre sem que haja um estímulo; e têm dificuldade em monitorar a fonte de informação $^{158}$.

Noutra perspectiva, independente da idade, as crianças que apresentam maior desenvolvimento cognitivo, mormente inteligência verbal e habilidades linguísticas são menos suscetíveis à sugestionabilidade ${ }^{159}$. Outros fatores vêm sendo analisados, ainda que as pesquisas não sejam conclusivas, apontam no sentido de que crianças com maior autoconceito e autoconfiança também sejam mais resistentes a sugestionabilidade. Por outro lado, há indícios de que crianças com retardo mental, mais criativas, mais tímidas, com menor capacidade de adaptação e de lidar com situações de estresse, estariam mais propensas ao estímulo externo ${ }^{160}$.

\footnotetext{
157 PIPE, M. E. et al., Recent research on children's testimony about experienced and witnessed events. Developmental Review, 24(4), 2004 apud STEIN, 2010, p. 169.

$158 \quad$ SAYWITZ, K. J.; LYON, T. D. Coming to grips with children's suggestibility. In: M. L. Eisen et al., Memory and suggestibility in the forensic interview. Mahwah: Lawrence Erlbaum, 2002 apud STEIN, 2010, p. 169.

159 CECI, S. J., et al., Unwarranted assumptions about children's testemonial accuracy. Annual Review Clinical Psychology, 3, 2007 apud STEIN, 2010, p. 169.

160 STEIN, 2010, p. 171-172.
} 
Já com relação ao contexto da entrevista, acredita-se que diversos elementos podem vir a sugestionar as crianças, entre eles: o uso de perguntas fechadas, sugestivas, repetidas, bem como de objetos que estimulem a imaginação; o tom emocional ou acusatório da entrevista; a pressão dos pares; a indução de estereótipos ou juízos de valor sobre algo ou alguém; e a repetição de entrevistas.

Em suma, Stein alerta sobre esta problemática:

\begin{abstract}
Se de um lado temos casos escandalosos de falsas denúncias de abusos sexuais, de outro, temos incontáveis casos de crianças vítimas de variadas formas de violência que, por sua vez, têm suas palavras desacreditadas e desmerecidas. Além das crianças já terem que lidar com a pressão usualmente exercida pelos seus agressores, é difícil encontrarem um ambiente adequado para serem ouvidas. E isto acontece, em regra, não porque as crianças não saibam ou não consigam falar, mas sim porque, quase sempre, os adultos que as questionam não sabem como perguntar. (...) Um longo período de tempo transcorrido até que sejam ouvidas, perguntas inadequadas, altamente sugestivas, repetidas inúmeras vezes em momentos variados por diferentes técnicos, terminam por comprometer não apenas a qualidade de seus relatos enquanto prova testemunhal como também contribuem para a revitimização das crianças numa situação abusiva ${ }^{161}$.
\end{abstract}

\title{
4.3.3. Sugestões para a redução das falsas memórias
}

Considerando as problemáticas que envolvem o depoimento em juízo, como a incidência de falsas memórias, se faz necessário abordar técnicas de entrevista que sejam capazes de não só melhorar a qualidade do testemunho, mas também que garantam o bem-estar de quem está depondo, visto que muitas vezes o evento em tela é emocionalmente negativo. A colheita do testemunho é um momento delicado e a postura do entrevistador interfere diretamente na qualidade deste, uma vez que se o profissional for ativo demais pode sugestionar o depoente e produzir falsas lembranças. Ademais, se este for inerte, pode não conseguir informações suficientes sobre o fato em questão e a ausência de detalhes poderá prejudicar a elucidação do caso em julgamento. 
Pensando nisso, algumas técnicas de entrevista foram desenvolvidas ao redor do mundo, com o intuito de minimizar ainda mais tais problemas. Dentre essas, a Entrevista Cognitiva, que foi desenvolvida em 1984 por Ronald Fisher e Edward Geiselman, ganhou maior notoriedade após ser reformulada e pesquisas comparativas sobre a efetividade desses procedimentos atestarem uma considerável vantagem desta sobre as demais, mormente com adultos. Seu desenvolvimento uniu conhecimentos da Psicologia social, principalmente sobre comunicação, com a Psicologia cognitiva, que estuda o funcionamento da memória, com vistas a obter maior quantidade e precisão dos relatos ${ }^{162}$.

Uma ressalva é feita quanto à utilização da Entrevista Cognitiva:

Apesar das amplas possibilidades de aplicação da EC, ela é contraindicada em entrevistas investigativas com suspeitos. Essa contraindicação está relacionada às distintas naturezas entre as entrevistas com vítimas e testemunhas e as entrevistas com suspeitos. Via de regra, ao se entrevistar um suspeito, este tende a ser pouco colaborativo, o que prejudica o uso das técnicas da EC (Memon, 1999). Logo, a entrevista com suspeitos requer o uso de técnicas especificamente voltadas para essa população, as quais diferem daquelas utilizadas na $\mathrm{EC}^{163}$.

Tendo em mente as principais falhas normalmente cometidas pelos profissionais forenses na colheita do depoimento, a Entrevista Cognitiva se propõe a solucioná-las, sendo organizada em cinco etapas: A construção do Rapport, recriação do contexto original, recordação livre, questionamento e fechamento da entrevista ${ }^{164}$.

A primeira etapa tem por objetivo personalizar a entrevista, deve-se começar com a abordagem de assuntos neutros, para que o entrevistador conheça o nível cognitivo e de desenvolvimento da linguagem do depoente e possa se ajustar a eles. É muito importante explicar os objetivos, regras e etapas do procedimento, bem como agradecer a participação da testemunha, demonstrando verdadeira empatia e atenção ao que está sendo dito. A 
finalidade é construir um ambiente acolhedor e propício para a fala. Dessa forma, é essencial afastar a crença de que existiria uma hierarquia entre as partes, transmitindo o controle para o entrevistado e estimulando uma postura ativa deste. Assim como, incentivá-lo a relatar todos os detalhes possíveis, ressaltando que, no entanto, ele não precisa saber responder todas as perguntas nem lembrar de tudo.

Em seguida, a recriação mental do contexto ambiental, perceptivo e afetivo do fato, que tem como objetivo aumentar as informações e detalhes que serão relatados na terceira etapa. Por sua vez, esta consiste na narrativa livre do entrevistado, na qual ele "tem liberdade para contar, da sua maneira, todas as informações que puder acessar na memória, sem interrupções" ${ }^{\prime 165}$. Assim, é fundamental que o profissional respeite as pausas feitas, sem aproveitá-las como uma oportunidade para interrompê-lo.

Já na quarta fase, o entrevistador poderá retomar o rapport se achar necessário, reforçando as regras básicas, como a liberdade do depoente de dizer que não sabe, não entendeu a pergunta ou não se lembra, assim como a liberdade de corrigir o entrevistador caso este tenha interpretado erroneamente o que foi relatado. Com vistas a evitar a sugestionabilidade e a formação de falsas memórias, deve-se privilegiar as perguntas abertas, em detrimento das fechadas, assim como evitar as perguntas múltiplas, tendenciosas e confirmatórias. Assim, "o entrevistador fará perguntas baseadas nas informações trazidas no relato livre, buscando coletar informações adicionais" ${ }^{166}$. E complementa Stein:

Ao fazer as perguntas, o entrevistador deve estar especialmente atento ao chamado "questionamento compatível com a testemunha". O questionamento compatível com a testemunha é baseado no princípio de que cada testemunha possui uma representação mental única do evento (Memon, Vrij e Bull, 1998). Logo, as perguntas devem ser formuladas a partir do relato que o entrevistado fez 
sobre o fato, e não com base em protocolos pré-estabelecidos (Fisher e Schreiber, $2006)^{167}$.

Por fim, a quinta etapa que, além do fechamento da entrevista, configura como mais um momento para o entrevistado acrescentar algo ao seu relato ou corrigir o entrevistador, depois que é feito o resumo do mesmo. É crucial estender a vida funcional da entrevista, isto é, deixar claro que o depoente poderá retomar a comunicação com o entrevistador caso se recorde de informações adicionais.

Portanto, a Entrevista Cognitiva apresenta diversas ferramentas para aumentar a qualidade do testemunho. Não obstante, sua implementação contém algumas limitações, principalmente de ordem prática, qual sejam, a necessidade de um treinamento específico, extenso e dispendioso dos profissionais que irão aplicá-la e condições físicas e tecnológicas adequadas, que também podem refletir em um gasto considerável. Além disso, depende de um certo nível cognitivo dos entrevistados, apresentando melhores resultados quando aplicados em adultos em comparação com crianças $^{168}$.

Há, ainda, uma preocupação quanto à adequação desta técnica com a rotina forense, nas palavras de Stein:

Via de regra, a EC é mais demorada que outros tipos de entrevista, consequentemente, durante um expediente normal de trabalho, um entrevistador que utiliza a EC conseguirá escutar menos pessoas em relação a outro que trabalhe com outra técnica. Em locais sobrecarregados de investigações, que têm uma quantidade muito grande de testemunhas para serem ouvidas, pode parecer problemático o uso da EC. Infelizmente, a necessidade de maior disponibilidade de tempo para o emprego da EC não é um aspecto que possa ser flexibilizado. Porém, esse dispêndio de tempo inicial com o uso da técnica de EC, ainda que pareça problemático, na realidade contribui para uma significativa economia de tempo e recursos financeiros. Isso ocorre porque tanto as investigações policiais, quanto as produções de provas dos processos judiciais, poderiam ser realizadas com base em evidências mais conclusivas e 
mais confiáveis, tornando-se um procedimento mais ágil, eficaz, e, em última análise, resultando em uma economia de tempo ${ }^{169}$. (grifo nosso)

No geral, avalia-se a Entrevista Cognitiva com um custo-benefício positivo. Apesar de depender de um investimento inicial considerável, uma vez incorporada ao sistema judicial, respeitando as peculiaridades de cada um, poderá trazer benefícios que o justificam. Além disso, o fato de diminuir os casos em que o ato precise se repetir compensa o tempo gasto com a entrevista. Porém, considerando que a utilização da Entrevista Cognitiva com crianças contém algumas limitações, há que se pensar em adaptações para aplicá-la neste grupo ou dar preferência para outras técnicas mais compatíveis.

Nesse sentido, tratando especificamente do testemunho infantil, Stein assevera:

[...] em muitos países, como Estados Unidos, Inglaterra, Escócia, Noruega e Espanha, reformas legais têm sido propostas com base nas pesquisas científicas na área da sugestionabilidade infantil. Nesses países, as crianças usualmente são entrevistadas por um profissional treinado em técnicas de entrevista investigativas cientificamente validadas para esse grupo etário. As entrevistas são gravadas e podem ser realizadas em sala de espelho unidirecional, ou através de circuito televisivo, evitando-se que a criança submeta-se à pressão natural de uma sala de audiências comum (Malloy et al., 2007). Tais modificações na forma de conduzir o depoimento de uma criança são medidas que visam a diminuir o estresse da criança na entrevista e, também, melhorar sua capacidade de recordação, além de diminuir a sugestionabilidade (Westcott, 2008) ${ }^{170}$.

Em paralelo, no Brasil foi implementada a Lei 13.431/17, que regulou o antigo depoimento sem dano, idealizado pelo desembargador José Antônio Daltoé Cezar, do Tribunal de justiça do Rio Grande do Sul. A referida lei prevê dois institutos que visam a proteção da criança e do adolescente, vítimas ou testemunhas em casos de violência, sejam eles: a escuta especializada ${ }^{171}$ e o depoimento especial ${ }^{172}$. O primeiro se dá perante

STEIN, 2010, p. 224.

Ibid., p. 174.

Art. $7^{\circ}$ Escuta especializada é o procedimento de entrevista sobre situação de violência com criança ou adolescente perante órgão da rede de proteção, limitando o relato estritamente ao necessário para o cumprimento de sua finalidade. 
órgão da rede de proteção, enquanto o segundo perante autoridade policial ou judiciária ${ }^{173}$. Apesar de trazer alguns avanços a referida lei não é isenta de críticas.

Assim, pontos positivos podem ser destacados desta lei, como a preocupação com o local em que o depoimento será colhido, devendo este ser apropriado e acolhedor para garantir a privacidade do depoente, assim como a previsão de gravação em áudio e vídeo do depoimento e sua transmissão em tempo real para a sala de audiência. Além disso, a preferência pela narrativa livre e a adaptação das perguntas à linguagem compatível com a do depoente. Por fim, a previsão da não repetição do depoimento especial, salvo quando justificada sua imprescindibilidade ${ }^{174}$.

Entretanto, ponto polêmico é a previsão do depoimento especial seguir o rito cautelar de antecipação de prova nos casos em que a criança tenha menos de sete anos ou nos casos de violência sexual. Primeiro, porque o instituto da prova antecipada não tem previsão no Código de Processo Penal, sendo aplicado, no que couber, o Código de Processo Civil. Nesse espírito, ainda que também esteja prevista na lei a garantia de ampla defesa do investigado, esta é omissa em prever a sua intimação para efetivar sua defesa.

Ademais, alerta Di Gesu sobre a temática:

Daí a importância de que o pedido de produção antecipada da prova seja antecedido de investigação sobre o fato e seu autor, haja vista que sem acusação, o suposto agressor sequer saberia o teor da colheita de prova, não tendo ciência, ao certo, do que se defender. Nesse ínterim, a investigação preliminar atuaria como um verdadeiro filtro, evitando acusações infundadas. Desta feita, diante da ausência de indícios (fumus comissi delicti), não são suficientes ao ajuizamento da ação penal, caberia ao Ministério Público pleitear ao juiz o arquivamento do processo $^{175}$.

172 Art. $8^{\circ}$ Depoimento especial é o procedimento de oitiva de criança ou adolescente vítima ou testemunha de violência perante autoridade policial ou judiciária.

173 DI GESU, 2019, p. 191.

174 DI GESU, 2019, p. 194.

$175 \quad$ Ibid., p. 197. 
Pelo exposto, apesar dos passos curtos, se verifica que o Brasil parece caminhar no mesmo sentido da comunidade internacional ao dedicar uma lei específica para tratar da colheita de depoimentos de crianças e adolescentes. Evidentemente, ainda não é o suficiente para superar todos os obstáculos que a existência das falsas lembranças impõem a prática jurídica, sendo fundamental avançar nos estudos da psicologia do testemunho. 


\section{CONSIDERAÇÕES FINAIS}

Diante do exposto, verifica-se que o processo penal se revela como uma atividade que busca reconstruir o delito e se desenvolve a partir da atuação dialética da acusação e da defesa, cada qual sustentando uma tese que, por meio da produção de provas, visa o convencimento do julgador. No entanto, admite-se que, por diversos motivos, essa reconstrução jamais alcançará a complexidade do fato em todos os seus aspectos.

A Constituição Federal e os diplomas legais penais estabelecem uma série de regras, princípios e garantias que regulam o procedimento, prevendo, inclusive, limitações ao poder punitivo do Estado. Destacam-se os princípios do devido processo legal, que preconiza o respeito pelas regras pré estabelecidas; o princípio da presunção de inocência, que assenta o estado de inocência do acusado até que se prove o contrário com o esgotamento de todos os recursos cabíveis, atrelado ao princípio do In Dubio Pro Reu; o princípio do contraditório e da ampla defesa, que buscam efetivar a defesa plena do acusado; e o princípio do livre convencimento motivado do juiz, do qual se extrai a necessidade de fundamentação das decisões.

Considere-se, ainda, a influência do sistema acusatório no processo penal brasileiro, que se baseia na oralidade, publicidade e na liberdade como regra. Além disso, deixa a cargo das partes a gestão da prova, garantindo a imparcialidade do juiz. Como consequência, este deverá se contentar com o que foi produzido pela acusação e pela defesa no decorrer do processo. Assim, há um conjunto de fatores que 
estabelecem limitações na condução do processo e na atuação dos atores do mesmo, de forma que a verdade que se constrói sobre o evento delitivo, conhecida como a verdade processual, nunca será a correspondência perfeita de tal evento.

Noutro giro, é cediço que, não raro, a prova oral, seja o depoimento de testemunhas, seja o interrogatório de vítimas, são utilizados como único meio de prova a embasar a decisão do julgador. No entanto, o processo de formação do testemunho e suas eventuais falhas que decorrem, em sua maioria, do próprio funcionamento da memória, como as falsas memórias, evidenciam a fragilidade desta prova e demonstram um alerta sobre a sua utilização quando não conjugada com outras provas.

Nesse ponto, se torna preciosa a interdisciplinaridade entre o Direito e a Psicologia para tratar do tema, focando no auxílio mútuo entre as disciplinas. Ao passo que diversos casos de erros judiciais ocasionados pela existência de falsas memórias serviram de base e contribuíram para um impulso das pesquisas sobre o tema pela Psicologia, esses mesmos estudos, ainda que não concluídos, permitem orientar os operadores do direito a lidarem com este fenômeno, inclusive, buscando formas de reduzir a sua incidência nas colheitas dos depoimentos judiciais.

Nesse sentido, diversos resultados de pesquisas feitas até aqui já demonstram descobertas importantes como: a forte influência das emoções sobre a memória, tanto positiva quanto negativamente; o desenvolvimento de teorias com o intuito de explicar a ocorrência das 
falhas mnemônicas; como determinadas características individuais são capazes de interferir nas recordações, entre outros.

Não obstante, existem algumas aplicações práticas para a rotina forense, que foram pensadas com base nesses estudos, como a Entrevista Cognitiva e outras que já vem sendo, inclusive, aplicadas no Brasil, como técnicas especiais para entrevista de crianças e adolescentes, considerando suas peculiaridades.

Com efeito, é possível traçar um paralelo entre a dificuldade de se abandonar essa inquietante busca pela verdade no processo penal brasileiro, que se manifesta como resquício das influências do sistema inquisitorial, assim como a dificuldade de se reconhecer a precariedade da prova oral, com a ânsia punitiva que persiste na sociedade brasileira e que, atualmente, aparece cada vez mais em voga.

O punitivismo - ainda que seletivo - almeja a condenação a qualquer custo, precisa que o processo construa uma narrativa dos fatos que permita e legitime a punição ao final. Logo, precisa, não só de uma verdade processual, mas uma verdade que se coadune ao seu interesse. Dessa forma, vai no sentido contrário de um processo justo, violando os princípios postos pela Constituição Federal.

Sem embargo, o punitivismo também se opõe ao garantismo penal e a segurança jurídica, na medida em que adota a lógica "dos fins que justificam os meios". De acordo com essa visão, o pensamento de sacrificar as garantias no decorrer do processo, como aceitar provas não tão contundentes ou que podem não refletir a realidade dos fatos - v.g. a prova oral contaminada de memórias falsas - se justifica em nome da suposta impunidade e do "bem comum". 
Diante desse cenário, enquanto a ciência não for capaz de apresentar resultados conclusivos sobre a origem e o funcionamento das falhas nas lembranças, bem como de distinguir estas das memórias verdadeiras, a confiabilidade neste meio de prova resta prejudicado. Portanto, é inegável que a existência das falsas memórias representam uma necessidade de cautela ao valorar a prova oral, sendo prudente que esta seja analisada em conjunto com outras provas produzidas no processo, como forma de garantir um processo justo. 


\section{REFERÊNCIAS BIBLIOGRÁFICAS}

ALMEIDA, Renato Santos de. Disponível em: https://www.conjur.com.br/2018-abr-05/especialistas-analisam-decisao-stfaceita-prisao-antecipada. Acesso em: 8 abr. 2019.

ALTAVILLA, Enrico. Psicologia Judiciária. $3^{\text {a }}$ ed. MIRANDA, Fernando de. (Trad.). v. 1-2. Coimbra: Arménio Amado, 1981.

AQUINO, José Carlos G. Xavier. A prova testemunhal no processo penal brasileiro. $5^{\text {a }}$ ed. São Paulo: Letras Jurídicas, 2015.

AROCA, Juan Montero. Principio del proceso penal. Una explicación basada en la razón. Valência: Tirant lo Blanch, 1997.

BARTLETT, F. C. Remembering: A study in experimental and social psychology. New York: Cambridge University Press, 1932.

BLAIR, I. V. et al., The reliability of the DRM paradigm as a measure of individual differences in false memories. Psychonomic Bulletin \& Review, 9(3), 2002.

BRAINERD, C. J. et al., Recollection rejection: False-memory editing in children and adults. Psychological Review, 110(4), 2003.

BRAINERD, C. J.; REYNA, V. F. The science of false memory. New York: Oxford University Press, 2005.

BRASIL, Constituição Federal, de 5 de outubro de 1988. Constituição da República Federativa do Brasil de 1988. Disponível em: http://www.planalto.gov.br/ccivil_03/constituicao/constituicao.htm. Acesso em: 10 jun. 2019.

BRASIL Decreto-Lei no 2.848, de 7 de dezembro de 1940. Código Penal. Disponível em: http://www.planalto.gov.br/ccivil_03/decretolei/del2848compilado.htm. Acesso em: 09 mai. 2019.

BRASIL. Decreto-Lei ${ }^{\circ}$ 3.689, de 3 de outubro de 1941. Código de Processo Penal. Disponível em: http://www.planalto.gov.br/ccivil_03/decreto-lei/del3689.htm. Acesso em: 11 abr. 2019. 
BRASIL. STF. HC: 126.292 SP, Relator: ministro TEORI ZAVASCKI, Data de Julgamento: 17/02/2016.

CARNELUTTI, Francesco. Verità, dubbio certeza. In: Rivista di Diritto Processuale. v. XX. Padova: CEDAM - Casa Editrice Dott Antonio Milani, 1965.

CECI, S. J., et al., Unwarranted assumptions about children's testemonial accuracy. Annual Review Clinical Psychology, 3, 2007.

CLEMENTE, M. (Coord.). Fundamentos de la psicología jurídica. Madrid: Pirâmide, 1998.

COUTINHO, Jacinto Nelson de Miranda (Coord.). O papel do novo juiz no processo penal. Crítica à Teoria Geral do Direito Processual Penal. 2001.

_ Glosas ao 'Verdade, Dúvida e Certeza' de Francesco Carnelutti, para os operadores do Direito. Disponível em: https://pt.scribd.com/document/240201544/Carnelutti-Verdade1-1-1. Acesso em: 18 abr. 2019.

DAMÁSIO, Antônio R. $O$ Erro de Descartes: emoção, razão e o cérebro humano. (Trad.). VICENTE, Dora; SEGURADO, Georgina. $8^{a}$ ed. São Paulo: Companhia das Letras, 2001.

DELGADO, Mauricio Godinho. Curso de direito do trabalho. $14^{\mathrm{a}}$ ed. São Paulo: LTr, 2015.

DI GESU, Cristina. Prova penal e falsas memórias. Porto Alegre: Livraria do Advogado, 2019.

FAZENDA, Irani. Práticas interdisciplinares na escola. $4^{\mathrm{a}}$ ed. São Paulo: Cortez, 1997.

FERRAJOLI, Luigi. Derecho y Razón - teoría del garantismo penal. IBÁÑEZ, Perfecto Andrés et al., (Trad.). 2ª ed. Madrid: Trotta, 1997.

FIORELLI, José Osmir; MANGINI, Rosana Cathya Ragazzoni. Psicologia jurídica. $9^{a}$ ed., Rev. e Atual. São Paulo: Atlas, 2018.

FISHER, R. P.; SCHREIBER, N. Interview protocols to improve eyewitness memory. In: TOGLIA, M. P. et al., The handbook of eyewitness psychology: v. 1. Memory for events. New Jersey: Lawrence Erlbaum, 2006. 
FRIJDA, N. H. Varieties of affects: Emotions and episodes, moods, and sentiments. In: EKMAN, P.; DAVIDSON, R. J. The nature of emotion. Oxford: Oxford University Press. 1994.

GALLO, D. A. et al., Reducing false recognition with criterial recollection tests: Distinctiveness heuristic versus criterion shifts. Journal of Memory and Language. 51, 2004.

GAZZANIGA M.S.; HEATHERTON T.F. Ciência psicológica: mente, cérebro e comportamento. Porto Alegre: Artmed; 2005.

GIACOMOLLI, Nereu José. A aproximação à garantia da motivação das decisões criminais: aspectos jurisprudenciais. Revista Ibero-Americana de Ciências Penais, 2005.

A fase preliminar do processo penal: crises, misérias e novas metodologias investigativas. Rio de Janeiro: Lumen Juris, 2011.

GIACOMOLLI, Nereu. Juizados Especiais Criminais. Lei 9.0099/95. $2^{\mathrm{a}} \mathrm{ed}$. Porto Alegre: Livraria do Advogado, 2002.

GOLDSCHMIDT, James. Problemas Jurídicos y Políticos del Proceso Penal. Barcelona: Bosh, 1935.

GONÇALVES, Victor Eduardo Rios; REIS, Alexandre Cebrian Araújo. Direito processual penal esquematizado. LENZA, Pedro (Coord.). $7^{\mathrm{a}} \mathrm{ed}$. São Paulo: Saraiva Educação, 2018.

IZQUIERDO, I. Memória. Porto Alegre: Artmed; 2000.

JOHNSON, M. K. et al., Source monitoring. Psychological Bulletin, 114, 1993.

LIMA, Renato Brasileiro de. Manual de processo penal: volume único. $4^{\mathrm{a}}$ ed. Rev., Ampl. e Atual. Salvador: JusPodivm, 2016.

LINDSAY, D. S.; JOHNSON, M. K. False memories and the source monitoring framework: Reply to Reyna and Lloyd (1997). Learning and Individual Differences, 12, 2000.

LOPES JÚNIOR, Aury. Direito processual penal. $11^{\mathrm{a}}$ ed. São Paulo: Saraiva, 2014. 
LÓPEZ, Mira Y. Manual de psicologia jurídica. Rio de Janeiro: Ed. Agir, 1955.

MALATESTA, Nicola Framarino dei. A Lógica das Provas em matéria Criminal. $2^{a}$ ed. SÁ, de José Alves de (Trad.). São Paulo: Livraria Teixeira.

MALLOY, L. et al., Children's eyewitness memory: Balancing children's needs and defandant's rights when seeking the truth. In: TOGLIA, M. P. et al., Handbook of eyewitness psychology: v. 1. Memory for events. Mahwah, NJ: Lawrence Erlbaum, 2007.

MELERO, Silva. La prueba procesual. t.1. Madrid: Revista de Derecho Privado, 1963.

MEMON, A. et al., Psychology and law: Truthfulness, accuracy and credibility. Berkshire: McGraw-Hill, 1998.

The cognitive interview. In: MEMON, A.; BULL, R. Handbook of the psychology of interviewing. West Sussex: Wiley \& Sons, 1999.

MUNOZ SABATE, L. et al. Introducción a la psicologia jurídica. México: Editorial Trillas, 1980.

NUCCI, Guilherme de Souza. Manual de processo penal e execução penal. $14^{\mathrm{a}}$ ed. Rio de Janeiro: Forense, 2017.

PERCHINUNNO, Vincenzo. Limiti soggettivi della testimonianza nel processo penale. Milano: Giuffrè, 1972.

PEZDEK, K.; TAYLOR, J. Memory for traumatic events for children and adults. In: M. L. Eisen et. al., Memory and suggestibility in the forensic interview. Mahwah: Lawrence Erlbaum, 2002.

PIPE, M. E. et al., Recent research on children's testimony about experienced and witnessed events. Developmental Review, 24(4), 2004.

POZO, J. I. Formação de conceitos artificiais. In: Teorias cognitivas da aprendizagem. Porto Alegre: Artmed, 1998.

PRADO, Geraldo. Sistema acusatório. A conformidade constitucional das leis processuais penais. $3^{\mathrm{a}}$ ed. Rio de Janeiro: Lumen Juris, 2005.

REALE, Miguel. Lições preliminares de direito. $27^{\mathrm{a}}$ ed. São Paulo: Saraiva, 2002. 
REYNA, V. F.; KIERNAN, B. The development of gist versus verbatim memory in sentence recognition: Effects of lexical familiarity, semantic content, encoding instructions, and retention interval. Developmental Psychology, 1994.

SÁ, Alvino Augusto de. Criminologia clínica e psicologia criminal. São Paulo: Editora Revista dos tribunais, 2007.

SAYWITZ, K. J.; LYON, T. D. Coming to grips with children's suggestibility. In: M. L. Eisen et al., Memory and suggestibility in the forensic interview. Mahwah: Lawrence Erlbaum, 2002.

SCHACTER, D. L. et al., Reductions in cortical activity during priming. Current Opinion in Neurobiology, 17(2), $2007 \mathrm{~b}$.

SCHACTER, D. L. The seven sins of memory: Insights from psychology and cognitive neuroscience. American Psychologist, 54(3), 1999.

SERAFIM, Antonio de Pádua; SAFFI, Fabiana. Psicologia e práticas forenses. Barueri: Manole, 2012.

SILVA, A. C. Pacheco e. Psiquiatria clínica e forense. São Paulo: Ed. Nacional, 1940.

STEIN, Lilian Milnitsky et al. Falsas memórias: fundamentos científicos e suas aplicações clínicas e jurídicas. [Edição Kindle]. Porto Alegre: Artmed, 2010.

TONINI, Paolo. A prova no processo penal italiano. RT, 2000.

TORNAGHI, Hélio. Instituições de processo penal. $2^{\mathrm{a}}$ ed., v. 4. Saraiva, 1977.

TOURINHO FILHO, Fernando da Costa. Processo penal. $33^{\mathrm{a}}$ ed. v. 3. Saraiva, 2011.

TRINDADE, Jorge. Manual de Psicologia Jurídica para operadores do direito. Porto Alegre: Livraria do Advogado, 2009.

WESTCOTT, H. L. Safeguarding witnesses. In: G. DAVIES et al., Forensic Psychology. Chichester: Wiley, 2008 